\title{
Size-dependent survival of European hake juveniles in the Mediterranean Sea
}

\author{
Manuel Hidalgo ${ }^{1,2}$, Alessandro Ligas ${ }^{3}$, José María Bellido ${ }^{4}$, Isabella Bitetto ${ }^{5}$, \\ Pierluiggi Carbonara ${ }^{5}$, Roberto Carlucci ${ }^{6}$, Beatriz Guijarro ${ }^{1}$, Angelique Jadaud ${ }^{7}$, \\ Giuseppe Lembo ${ }^{5}$, Chiara Manfredi ${ }^{8}$, Antonio Esteban ${ }^{4}$, Germana Garofalo ${ }^{9}$, \\ Zdravko Ikica ${ }^{10}$, Cristina García ${ }^{2}$, Luis Gil de Sola ${ }^{2}$, Stefanos Kavadas ${ }^{11}$, Irida Maina ${ }^{11}$, \\ Letizia Sion ${ }^{6}$, Stefania Vittori ${ }^{12}$, Nedo Vrgoc ${ }^{13}$ \\ ${ }^{1}$ Instituto Español de Oceanografía, Centro Oceanográfico de les Baleares, Muelle de Poniente s/n, Apdo. 291, \\ Palma de Mallorca 07015, Spain. \\ ${ }^{2}$ Instituto Español de Oceanografía, Centro Oceanográfico de Málaga, Muelle Pesquero s/n, Fuengirola, Málaga 29640, \\ Spain. \\ (MH) (Corresponding author) E-mail:jm.hidalgo@ieo.es.ORCID iD; https://orcid.org/0000-0002-3494-9658 \\ (BG) E-mail: beatriz.guijarro @ieo.es. ORCID iD: https://orcid.org/0000-0002-2083-4681 \\ (CG) E-mail: cristina.garcia@ieo.es. ORCID iD: https://orcid.org/0000-0003-2767-4200 \\ (LGS) E-mail: gildesola@ieo.es. ORCID iD: https://orcid.org/0000-0003-1987-9716 \\ ${ }^{3}$ Consorzio per il Centro Interuniversitario di Biologia Marina ed Ecologia Applicata (CIBM), viale N. Sauro 4, I-57128, \\ Livorno, Italy. \\ (AL) E-mail: ligas@cibm.it. ORCID iD: https://orcid.org/0000-0003-1036-3553 \\ ${ }^{4}$ Instituto Español de Oceanografía, Centro Oceanográfico de Murcia, c/ Varadero no 1, 30740-San Pedro del Pinatar, \\ Murcia, Spain \\ (JMB) E-mail: josem.bellido@ieo.es. ORCID iD: https://orcid.org/0000-0002-6887-4391 \\ (AE) E-mail: antonio.esteban @ieo.es. ORCID iD: https://orcid.org/0000-002-2896-7972 \\ ${ }^{5}$ COISPA Tecnologia \& Ricerca, Stazione Sperimentale per lo Studio delle Risorse del Mare, Via dei Trulli, 18/20, 70126, \\ Bari, Torre a Mare, Italy. \\ (IB) E-mail: bitetto@coispa.it. ORCID iD: https://orcid.org/0000-0002-8497-1642 \\ (GL) E-mail: lembo@ coispa.it. ORCID iD: https://orcid.org/0000-0002-9899-6189 \\ (PC) E-mail: carbonara@ coispa.it. ORCID iD: https://orcid.org/0000-0002-2529-2535 \\ ${ }^{6}$ Department of Biology University of Bari Aldo Moro, via Orabona 4 70121, Italy. \\ (RC) E-mail: roberto.carlucci@ uniba.it. ORCID iD: https://orcid.org/0000-0002-9287-6936 \\ (LS) E-mail: letizia.sion @ uniba.it. ORCID iD: https://orcid.org/0000-0002-0308-1841 \\ ${ }^{7}$ UMR MARBEC “Marine Biodiversity, Exploitation \& Conservation”, IFREMER-LHM, avenue Jean Monnet 34203 Sète \\ cedex, France. \\ (AJ) E-mail: Angelique.Jadaud@ifremer.fr. ORCID iD: https://orcid.org/0000-0001-6858-3570 \\ ${ }^{8}$ Laboratorio di Biologia Marina e Pesca di Fano, Dip.to Bi.Ge.A. - Università di Bologna, viale Adriatico 1/n, 61311 Fano \\ (PU), Italy. \\ (CM) E-mail: chiara.manfredi3@unibo.it. ORCID iD: https://orcid.org/0000-0002-2852-4856 \\ ${ }_{9}^{9}$ Istituto per l'Ambiente Marino Costiero, Consiglio Nazionale delle Ricerche, Mazara Del Vallo, TP, Italy. \\ (GG) E-mail: germana.garofalo@iamc.cnr.it. ORCID iD: https://orcid.org/0000-0001-9117-6252 \\ ${ }^{10}$ Institute of Marine Biology, University of Montenegro, and the address is (in case it is required): Dobrota b.b., P.O. Box \\ 69, 85330 Kotor, Montenegro. \\ (ZI) E-mail: zdikica@ac.me. ORCID iD: https://orcid.org/0000-0003-3157-0500 \\ ${ }^{11}$ Institute of Marine Biological Resources and Inland Waters, Hellenic Centre for Marine Research (IMBRIW/HCMR), \\ $46.7 \mathrm{~km}$ Athens Sounio ave. P.O. Box 712, 19013 Anavyssos, Attiki, Greece. \\ (SK) E-mail: stefanos@ @cmr.gr. ORCID iD: https://orcid.org/0000-0003-3473-9084 \\ (IM) E-mail: imaina@hcmr.gr. ORCID iD: https://orcid.org/0000-0001-5244-2722 \\ ${ }^{12}$ Department of Life and Environmental Science, University of Cagliari, Via T. Fiorelli 1, 09126 Cagliari, Italy. \\ (SV) E-mail ste.vittori@gmail.com. ORCID iD: https://orcid.org/0000-0001-6857-0470 \\ ${ }^{13}$ Institute of Oceanography and Fisheries Setaliste Ivana Mestrovica 6321000 Split, Croatia. \\ (NV) E-mail: vrgoc@izor.hr. ORCID iD: https://orcid.org/0000-0002-5208-4512
}

Summary: Most studies on European hake focus on the recruitment process and nursery areas, whereas the information is comparatively limited on the ecology of the juvenile stage ( $c$. second year of life) - the one most exploited by the Mediterranean trawl fisheries. Using information of the MEDITS programme, we provide a spatial and temporal assessment of the influence of body size and growth on hake survival from recruits (age 0) to juveniles (age 1), along with the impact of surface temperature and chlorophyll variability. At a biogeographic scale, size-dependent survival is supported, with areas with higher mean length of recruits and juveniles yielding higher survival. A similar pattern was observed at interannual level 
in some western Mediterranean areas, also mediated by a density-dependent effect on growth. However, the most recurrent inter-annual pattern was a negative effect of size on survival, which could be attributed to potential ontogenetic changes in catchability and underrepresentation of intra-annual recruitment pulses that are seasonally inaccessible to the MEDITS survey. Results also evidence that survival in the Alboran and Adriatic seas is dependent on the primary production variability, and that Corsica and Sardinia could be potential feeding grounds receiving juveniles from neighbouring areas. The present study reveals the importance of size- and growth-dependent survival in the juvenile stage of European hake in the Mediterranean Sea.

Keywords: juvenile survival; European hake; Mediterranean Sea; size dependence.

\title{
Influencia del tamaño en la supervivencia de juveniles de merluza en el mar Mediterráneo
}

\begin{abstract}
Resumen: La mayoría de estudios de merluza europea se han centrado en el proceso de reclutamiento y sus hábitats preferentes, mientras que la información es mucho más escasa sobre los procesos ecológicos asociados a la fase juvenil (i.e. segundo año de vida aproximadamente), la cual se considera la más impactada por la pesca de arrastre en el Mediterráneo. En este estudio usamos la información del programa MEDITS para investigar, temporal y espacialmente, la posible influencia del tamaño corporal y el crecimiento sobre la supervivencia desde la fase de reclutas (edad 0) a la de juveniles (edad 1). También se ha evaluado la posible influencia de la temperatura y la clorofila superficial. A una escala biogeográfica, los resultados corroboran la influencia de la talla sobre la supervivencia, con mayor supervivencia asociada a áreas de mayor talla media de reclutas y juveniles. El mismo patrón se observó a escala interanual en algunas zonas del oeste el Mediterráneo, en las cuales se detectó también un efecto de denso-dependencia en el reclutamiento. Sin embargo, el patrón interanual más recurrente fue un efecto negativo de la talla sobre la supervivencia, que podría ser atribuido tanto a cambios ontogenéticos en la capturabilidad de los peces como a la posible infraestimación de los pulsos interanuales de reclutamiento que pueden resultar estacionalmente inaccesibles a las campañas MEDITS. Los resultados también evidencian que la supervivencia en Alborán y el Adriático depende de la variabilidad de la producción primaria, y que Córcega y Cerdeña podrían ser potencialmente áreas de alimentación que reciben juveniles de áreas adyacentes. El presente estudio evidencia la importancia de la influencia de la talla corporal y el crecimiento sobre la supervivencia juvenil de la merluza europea en el mar Mediterráneo.
\end{abstract}

Palabras clave: supervivencia juvenil; merluza europea; mar Mediterráneo; dependencia del tamaño.

Citation/Cómo citar este artículo: Hidalgo M., Ligas A., Bellido J.M., Bitetto I., Carbonara P., Carlucci R., Guijarro B., Jadaud A., Lembo J., Manfredi C., Esteban A., Garofalo G., Ikica Z., García C., Gil de Sola L., Kavadas S., Maina I., Sion L., Vittori S., Vrgoc N. 2019. Size-dependent survival of European hake juveniles in the Mediterranean Sea. Sci. Mar. 83S1: 207-221. https://doi.org/10.3989/scimar.04857.16A

Editor: G. Tserpes.

Received: March 20, 2018. Accepted: July 25, 2018. Published: March 18, 2019.

Copyright: (C) 2019 CSIC. This is an open-access article distributed under the terms of the Creative Commons Attribution 4.0 International (CC BY 4.0) License.

\section{INTRODUCTION}

The European hake (hereafter hake), Merluccius merluccius, is one of the most studied demersal commercial species in the southern European Seas due to its economic and ecological importance. In the eastern Atlantic, following an overall decrease in fishing pressure, many northern European stocks including hake are now exploited sustainably or showing signs of recovery (Fernandes et al. 2017), and along with increasing temperatures this has triggered an expansion of the species into the North Sea (Cormon et al. 2014, Baudron and Fernandes 2015). In the Mediterranean Sea, however, the status of fisheries and stocks has for several years been a cause for concern (Vasilakopoulos et al. 2014, Fernandes et al. 2017), with hake as the most generalized example (STECF 2015, GFCM 2016). Owing to the general lack of information on hake adults from fisheries-dependent and -independent data, almost all studies on hake in the Mediterranean Sea focus on the recruitment process: spatial-temporal dynamics (e.g. Abella et al. 2005, Bartolino et al. 2008a, Hidalgo et al. 2008), nursery modelling (e.g. Lembo et al. 2000, Colloca et al. 2009, Druon et al. 2015), or biological information such as growth (e.g. Morales-Nin and Moranta 2004, Mellon-Duval et al. 2010, Ligas et al. 2015), diet (Ferraton et al. 2007) and physiological and body condition (e.g. Hidalgo et al. 2009, Rueda et al. 2015, Cantafaro et al. 2017). Most of these studies focus on the first year of life (recruits) and few of them investigate an important ontogenetic stage from the ecological and fisheries perspective: the juvenile stage prior to maturation.

Although juvenile fish is a general concept that spans various stages between birth and adulthood, this period includes numerous important ontogenetic and critical life stages. From an applied perspective, fisheries scientists working in demersal fisheries often refer to the juvenile stage (also referred as postrecruits or sub-adults, Levin and Stunz 2005) as the period that ranges from settlement to the bottom or from recruitment to the fishery to the first reproductive period (e.g. Ciannelli et al. 2007). In the case of hake, this period is mainly framed in the second year of life (e.g. Hidalgo et al. 2008, Recasens et al. 2008, see methods for specific details), in which hake already have an active predatory activity, a high food intake of a mainly ichthyophagous diet composed primarily of pelagic fish, and a still high somatic growth rate. Recruits and juveniles are those most impacted by bottom trawl fisheries in the Mediterranean (Colloca et al. 2013), and juveniles can still be considered relatively well sampled by bottom trawling, through both the monitoring of commercial fisheries and scientific bottom trawl surveys. Larger individuals 
are less available to bottom trawl gears (thanks to spawning refugia; Colloca et al. 2013, Caddy 2015 and references therein), although they are targeted by other commercial gears such as longlines and gillnets in some Mediterranean areas (Aldebert et al. 1993, Sbrana et al. 2007). All of these findings evidence the high importance of having a complete view of the juvenile life stage to understand how the combination of ecological, environmental and fishing impact shapes natural mortality (Jørgensen et al. 2013), a key population dynamics parameter normally assumed to be constant and age-independent in the assessment frameworks (Abella et al. 1997, Caddy 2015).

Numerous studies have reported size- and growthdependent survival in juvenile fish (Ciannelli et al. 2007, Le Pape and Bonhommeau et al. 2015 and references therein). The increase of survival at high lengths is often explained as the result of size-selective mortality, a common mechanism in fish population dynamics ('bigger is better', e.g. Sogard 1997, Suthers 1998), for which small fish of a given species or those with slower growth display higher mortality rates. It is indeed expected that food limitation and/or competition can influence survival via density-dependent regulation mechanisms. Density-dependent growth (and size) has been proposed as a primary mechanism of regulation of fish populations (Lorenzen and Enberg 2002), including hake (Hidalgo et al. 2014, Cantafaro et al. 2017). However, the literature shows a range of contrasting (and often contradictory) studies from individual to population scale between species (Le Pape and Bonhommeau et al. 2015). Indeed, contrasting regulatory mechanisms have been described for hake in the Atlantic stocks, with the southern Atlantic stock more dependent on somatic growth to regulate the population dynamics than the northern stock (Hidalgo et al. 2014). It is also noteworthy that estimates of survival could be the consequence of transboundary movement of juveniles between areas (geographical sub-areas, GSAs, in the Mediterranean case) used to compile fisheries and ecosystem data, and in some cases to perform analytical fisheries assessment. This implies that the spatial and demographic structure of marine populations is more complex than is currently reported, in accordance with the general acceptance of mismatch between biological and management structures currently used in fisheries assessment frameworks (Kerr et al. 2017, Goethel and Berger 2017).

The MEDITS survey provides a unique opportunity to investigate the spatial and temporal patterns of juvenile survival using information from areas that are regularly sampled on an annual basis according a common and standardized methodology (Bertrand et al. 2002, Anonymous 2017). We here investigate the potential influence of size of juveniles of the current year, size of recruits of the previous year, and differential growth between them, along with information on environmental variables such as sea surface temperature and chlorophyll $a$, in winter and spring. Given the known sex differences in growth for this species as it approaches the reproductive stage, male and female information was analysed separately. We hypothesize that size can influence juvenile survival, but that this effect differs between sex and geographic subareas over the Mediterranean Sea. The study also discusses the potential utility of the results obtained to improve the current assessment of hake stocks or to implement marine spatial planning in fisheries management.

\section{MATERIALS AND METHODS}

\section{Sampling}

Data have been obtained since 1994 from the EU International Mediterranean Bottom Trawl Survey (MEDITS) conducted on an annual base in spring and early summer on demersal grounds from 10 down to $800 \mathrm{~m}$ depth. A stratified random sampling design was adopted with five bathymetric strata: 10-50, 51-100, 101-200, 201-500 and 501-800 m. Specific details of the sampling methods can be found in Bertrand et al. (2002) and Anonymous (2017).

The study combines information for 12 geographical subareas (GSA): the northern Alboran Sea (GSA-1), the Balearic Islands (GSA-5), northern Spain (GSA-6), the Gulf of Lions (GSA-7), eastern Corsica (GSA-8), the Ligurian and northern Tyrrhenian seas (GSA-9), the southern and central Tyrrhenian Sea (GSA-10), Sardinia (GSA-11), southern Sicily (GSA-16), the northern-central Adriatic (GSA-17), the southern Adriatic (GSA-18) and the western Ionian (GSA-19).

\section{Density and annual abundances indices}

European hake individuals caught in each haul were counted, sexed and measured to the half $\mathrm{cm}$ below. Abundance data were standardized to number of individuals per $\mathrm{km}^{2}$ using the swept area to obtain density estimates per haul, size class and year. To segregate information of non-sexed individuals into males and females, a sex-ratio vector was calculated for each geographical subarea. Density information for males and females was then grouped into recruits and juveniles according to growth information from GarcíaRodriguez and Esteban (2002): recruits (age 0, $\leq 15.5$ $\mathrm{cm}$ ), juvenile males (age $1,>15.5 \mathrm{~cm}$ and $\leq 29 \mathrm{~cm}$ ) and juvenile females (age $1,>15.5 \mathrm{~cm}$ and $\leq 32.5 \mathrm{~cm}$ ). A weighted mean length per haul, sex, age class and year was also calculated. For plotting purposes, density per haul information was averaged for each year on a $0.5 \times 0.5^{\circ}$ grid. The stratified mean equation by Souplet (1996) provided by Anonymous (2017, page 69) was applied to calculate abundance indices per year, sex and age class. For each year, sex and age class, a weighted mean length was also calculated.

\section{Survival and growth calculations}

Survival and growth estimates per year and GSA were calculated separately for males and females using annual abundance and mean length indices, respectively. Given two consecutive years, $t-1$ and $t$, we calculated an index of survival $(S)$ between age 0 and the ensuing age 1 as follows: 


$$
S_{\mathrm{t}}=X_{1, \mathrm{t}}-X_{0},(\mathrm{t}-1)
$$

where $X_{1, \mathrm{t}}$ and $X_{0,(\mathrm{t}-1)}$ are the natural logarithm of the annual abundance index of age 1 and age 0 hake, respectively. Differential growth $(G)$ between years was obtained using the same approach as follows:

$$
G_{\mathrm{t}}=Y_{1, \mathrm{t}^{-}} Y_{0,(\mathrm{t}-1)}
$$

where $Y_{1, \mathrm{t}}$ and $Y_{0,(\mathrm{t}-1)}$ are the natural logarithm of the annual mean length of age 1 and age 0 hake, respectively.

\section{Environmental covariates and fishing pressure}

To explore the potential influence of inter-annual environmental variability of a given geographical subarea on juvenile survival, satellite data for sea surface temperature and surface chlorophyll $a$ resulted from MODIS-Aqua and NPP-VIIRS sensor measurements already processed with regional ocean colour algorithms (resolution $1 \mathrm{~km}$, daily data) were downloaded from the MyOcean database (http://marine.copernicus. eu/web/69-interactive-catalogue.php) and used as common environmental variables for all the study areas. For each GSA, monthly averages were calculated over the gridded information. To capture potential different seasonal effect of temperature and productivity on survival, sea surface temperature and chlorophyll $a$ were averaged for two contrasting seasons: winter (December-February), which is often related to the population dynamics of several species (e.g. Hidalgo et al. 2011, Puerta et al. 2014); and spring (March-May), concurrent with the MEDITS surveys.

As there was no indicator of fishing pressure that was homogeneous in all analysed GSAs for the entire time period, we used the fishing pressure indicators calculated by Kavadas et al. (2015) for three years (1994, 2004 and 2014; see Supplementary Material for calculation procedure) to indirectly check the influence of fishing on survival using the residuals of the global model (see below).

\section{Statistical analyses}

Prior to the statistical analyses, density-dependent relationships were checked for survival, differential growth and mean length (ML) of juveniles, against abundance of recruits and juveniles. In addition, mean survival estimates per GSA were compared against the growth and ML of both recruits and juveniles. Non-linear regressions (general additive models) were used in this study for visual representation of the functional form of these relationships. It is worth noticing that density-dependent relationships were assessed by combining information of males and females, while relationships between mean values per GSA were investigated by sex.

The statistical procedure for analysing the influence of size, growth and environmental variables on survival has two steps and was applied separately for males and females. First, for each GSA, time series of survival were modelled by applying linear models in terms of differential growth, ML of recruits of the previous year ( $t-1)$, ML at time $t$ of juveniles and, sea surface temperature and chlorophyll in the two seasons. The best model was obtained by minimizing the Akaike information criterion. For every model, residuals were checked for variance homogeneity and absence of temporal autocorrelation in the residuals. Second, we compared the relative influence of the most recurrent driver observed across all the geographic subareas to assess its relative influence on survival variability. To do that, we applied a global model with all time series (both response and covariate) normalized to mean 0 and variance 1 and pooled in a unique and centred (i.e. intercept equals 0) linear model to compare how the size (slope) of a given effect changes for each geographic subarea. Residuals obtained for these final models for males and females were averaged per GSA and correlated with the fishing pressure indicator (FPI) for each year available (1994, 2004 and 2014) using Spearman rank correlations.

\section{RESULTS}

\section{Mean spatial pattern of mean densities and mean lengths}

Figure 1 shows the spatial information used in this study to calculate survival, such as the mean density of recruits, male and female juveniles, and the estimates of the ML for the same age and sex groups. Given that the spatial pattern of recruits does not differ by sex, they were combined for plotting purposes. High abundance of recruits was observed in the Spanish mainland coasts, the Gulf of Lions, southeast Sardinia and the Italian coasts of the Ligurian and northern Tyrrhenian Sea, coinciding with low ML values of those recruits. By contrast, intermediate to low values of mean density of recruits (consistent with higher ML) were observed in the Alboran Sea, the Balearic Islands, eastern Corsica, northern and eastern Sardinia, the Strait of Sicily, and the western Ionian and the northern Adriatic seas. The highest ML of recruits was found around eastern Corsica and Sardinia and in the western Ionian and northern Adriatic seas, coinciding with the intermediate or lowest values of recruit density. In general, juvenile males and females showed similar patterns with intermediate values of density along the Spanish coast and in the Gulf of Lions and the Ligurian and northern Tyrrhenian seas. The highest density of hake juveniles was found in western Sardinia.

The lowest values of ML were observed along the Spanish coast and in the Ligurian and northern Tyrrhenian seas. For females, the lowest ML values were observed in the southern Adriatic Sea, while intermediate to high ML values were found in the Alboran Sea, the Gulf of Lions, the Balearic Islands, the Strait of Sicily and the northern Adriatic Sea.

\section{Temporal patterns of abundance indices and mean lengths}

Figure 2 shows for each GSA the time series of abundance indices (in a log scale) and the ML of 

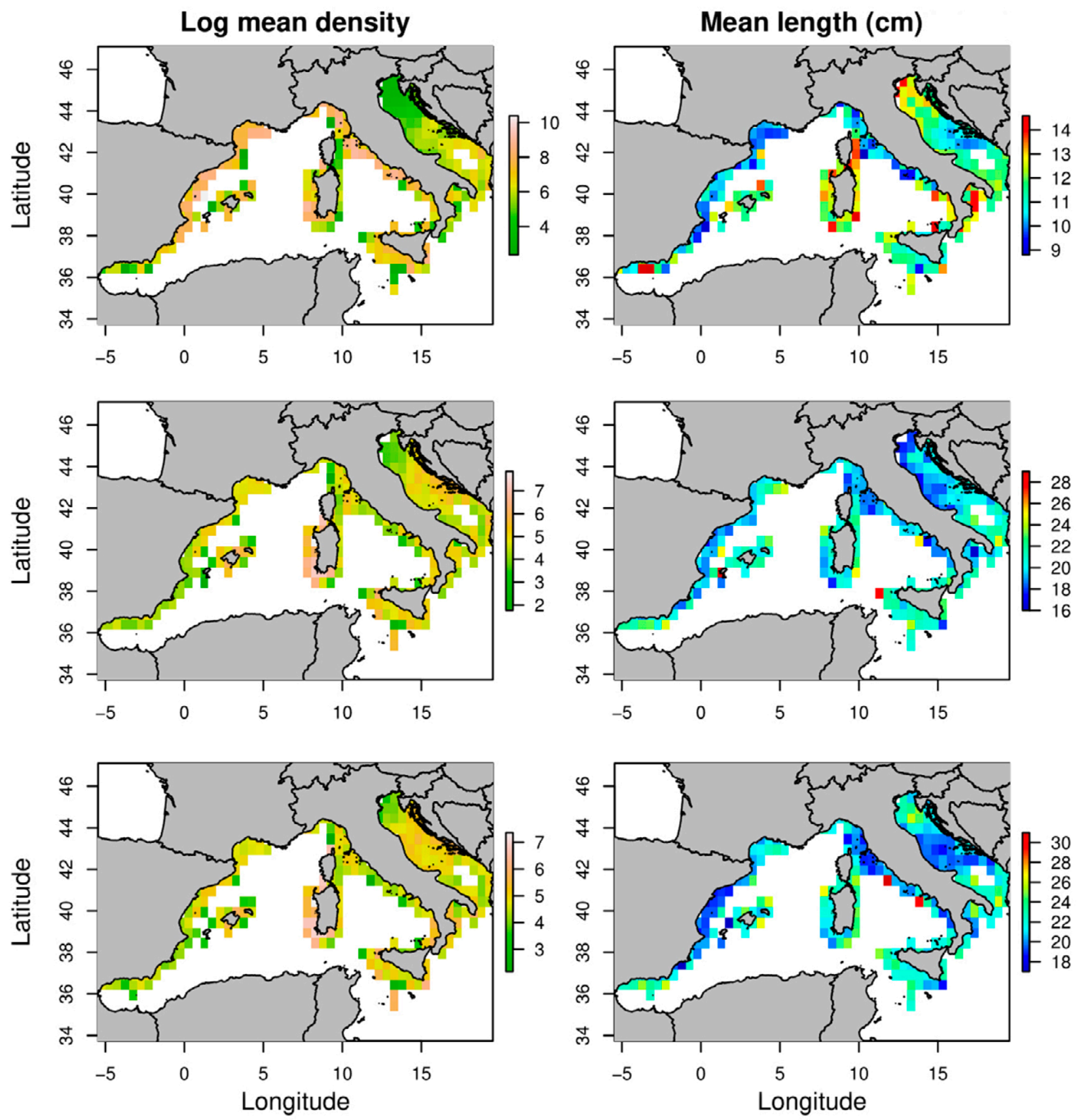

Fig. 1. - Mean log density (left column) and mean length (right column) per grid $\left(0.5 \times 0.5^{\circ}\right)$ for recruits (above), juvenile males (centre) and juvenile females (bottom) calculated over the whole period. Note that for each map the scale used for the colour legend differs.

recruits and juvenile males and females. Time series are segregated into two contiguous plots: the western Mediterranean, including GSAs 1, 5, 6, 7 and 8 , and the central Mediterranean, including areas $9,10,11,16,17,18$ and 19. In general, abundance indices of recruits showed a fluctuating pattern that differed among areas, with larger spatial variation in the western Mediterranean. Males and females showed similar patterns, with higher spatial consistence in the central and western Mediterranean, with the sole exceptions of eastern Corsica (GSA-8) and Sardinia (GSA-11), which displayed stronger fluctuations with lower and higher values than the average, respectively.
The temporal pattern of the ML of recruits displayed large fluctuations (Fig. 3). In the western Mediterranean, the northern Spanish coast and the Gulf of Lion (GSA-6 and GSA-7) showed a coherent fluctuating behaviour and an increasing long-term pattern during the study period. Eastern Corsica showed higher mean values consistent with the lowest densities observed. ML of recruits showed overall higher values in the central Mediterranean than in the western Mediterranean, with the exception of the Ligurian and the northern Tyrrhenian seas (GSA-9). The temporal pattern of ML of juveniles was also generally consistent between sexes in the western Mediterranean, while in the central Mediterranean female ML showed greater 

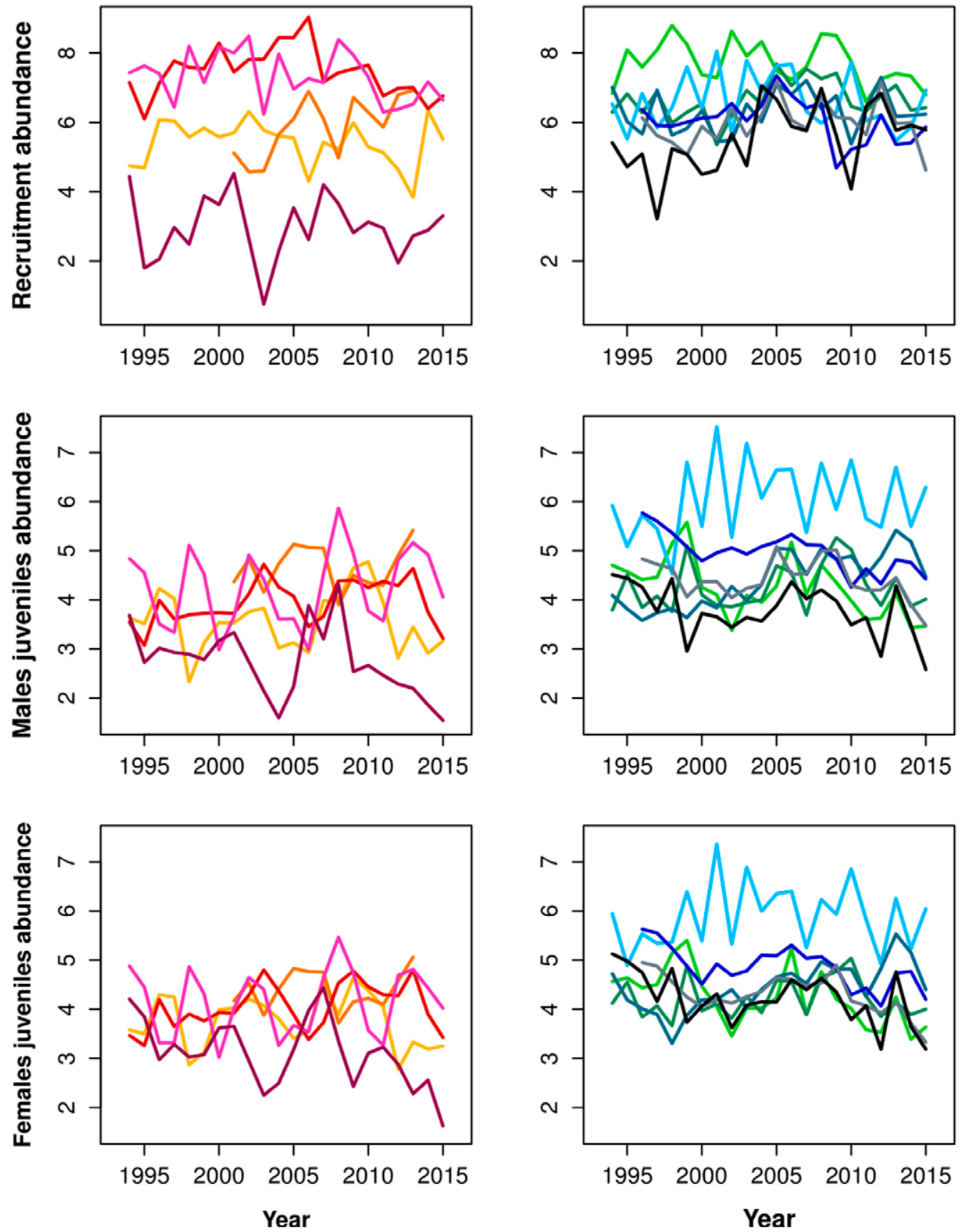

Fig. 2. - Abundance indices (log scale) for recruits (above), juvenile males (centre) and juvenile females (bottom) calculated for each GSA. GSAs of the western Mediterranean (1 to 8 ) are coded in yellow-red colours and those of the central Mediterranean (9 to 19) are coded in green-blue-black.

fluctuations, particularly in Sardinia (GSA-11) and the Strait of Sicily (GSA-16). The fluctuating pattern of juvenile ML was also generally higher in the western Mediterranean than in the central Mediterranean.

\section{Temporal and large-scale patterns of survival and growth per GSA}

Figure 4 shows the time series estimates of survival and growth per sex and GSA. Survival values ranged between -5 and 2 . Values above zero indicate that for a given GSA, the number of juveniles in a given year was higher than the number of recruits in the previous year. This is the case for most years in Corsica (GSA-8) and Sardinia (GSA-11), and for few years in the Balearic Islands (GSA-5) and the western Ionian Sea (GSA-19). The lowest values of survival in the western Mediterranean occurred along the northern Spanish (GSA-6) coast and in the Gulf of Lions (GSA-7), which showed a similar temporal pattern. In the central Mediterranean, the lowest values of survival were observed in the Ligurian and northern Tyrrhenian seas (GSA-9). The fluctuation pattern was very similar between sexes in all GSAs, with a 

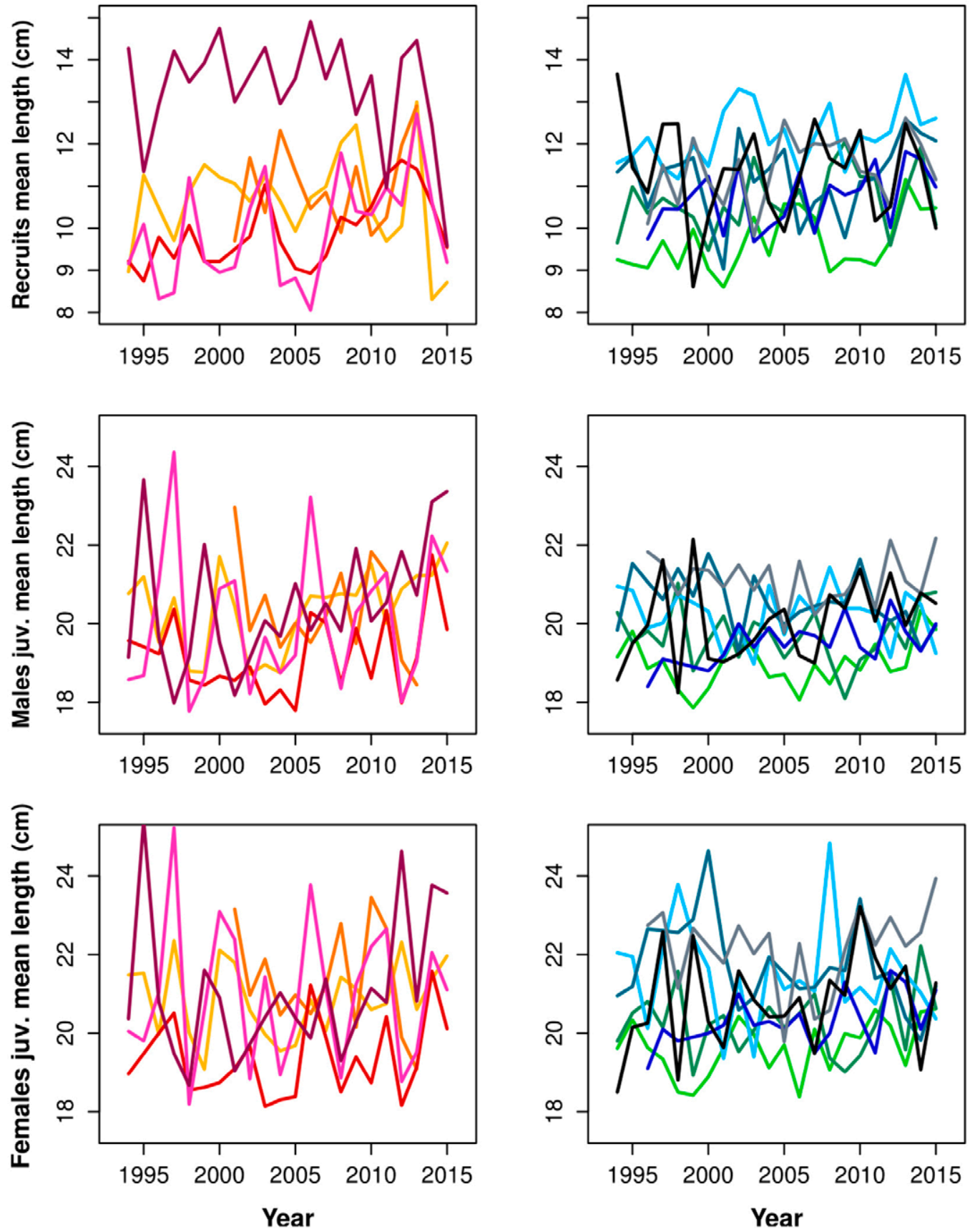

Fig. 3. - Mean lengths for recruits (above), juvenile males (centre) and juvenile females (bottom) calculated for each GSA. GSAs of the western Mediterranean (1 to 8) are coded in yellow-red colours and those of the central Mediterranean (9 to 19) are coded in green-blue-black.

slightly higher degree of variability in the western than in the central Mediterranean.

In the case of growth (Fig. 4), the western Mediterranean GSAs also displayed higher variability within and among areas than the central Mediterranean. As observed in the survival and ML pattern, the northern Spanish coast and the Gulf of Lions displayed a similar fluctuating pattern. The growth rates in the recruit to juvenile phase observed in eastern Corsica were the lowest, despite a very high growth rate during the first year of life, as proved by the higher ML of recruits in this area.
On a broad Mediterranean scale, GSAs with higher ML of recruits and juveniles yielded higher survival for both sexes (Fig. 5), with this pattern being more clearly observed in the ML of recruits. As a consequence, survival was higher in areas with smaller differential growth between consecutive years (Fig. 5).

\section{Density dependence in survival, growth and size}

Significant density-dependent survival was observed in all GSAs, though it was stronger in the western areas, Sardinia and the western Ionian Sea (Fig. 6). 
GSA 1 GSA 5 GSA 6 GSA 7 GSA 8 GSA 9 GSA 10 GSA 11 GSA 16 GSA 17 GSA 18 GSA 19
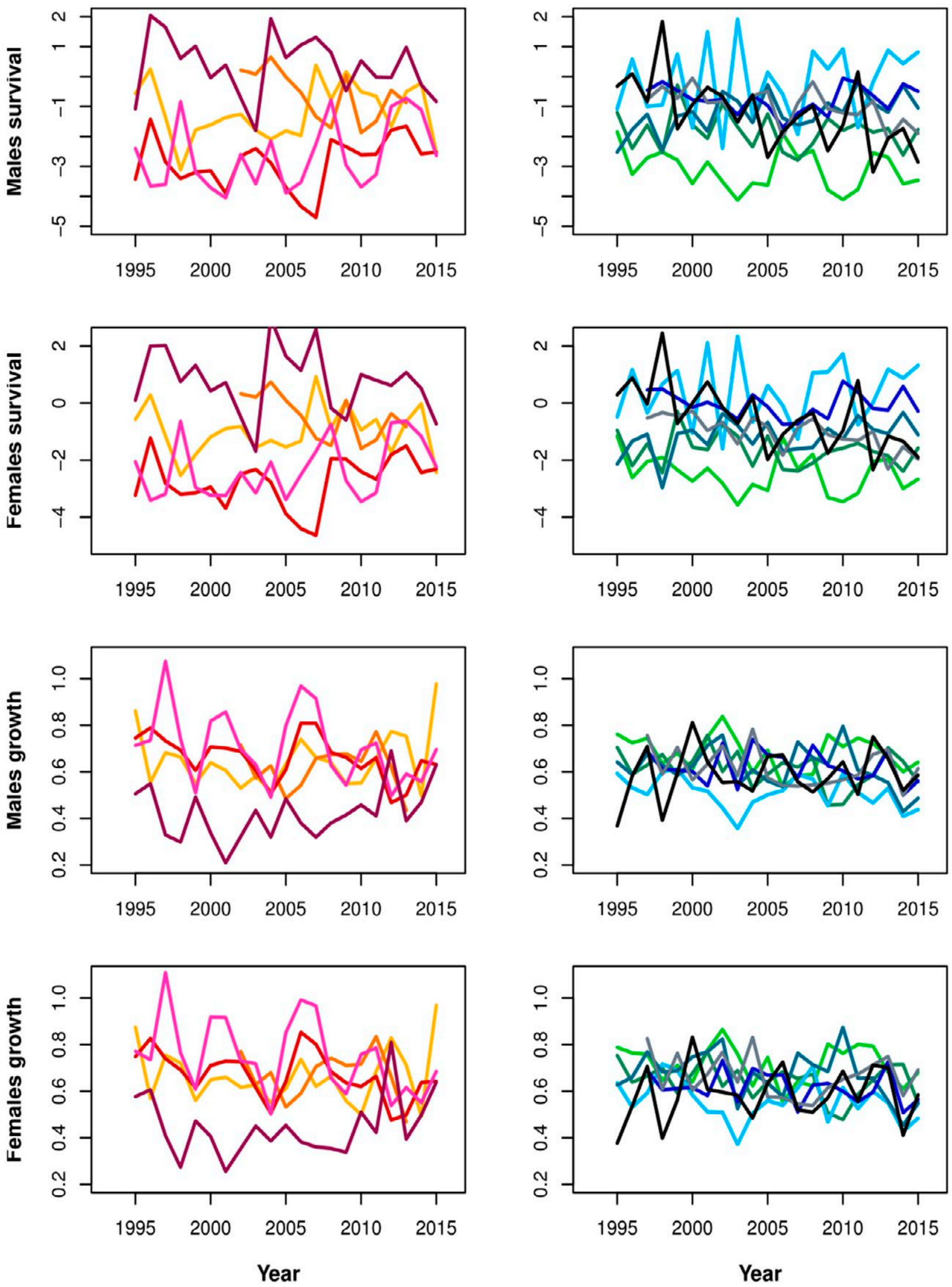

Fig. 4. - Juvenile survival (left) and growth (right) for males (above) and females (bottom) calculated for each GSA. GSAs of the western Mediterranean (1 to 8 ) are coded in yellow-red colours and those of the central Mediterranean ( 9 to 19) are coded in green-blue-black. 

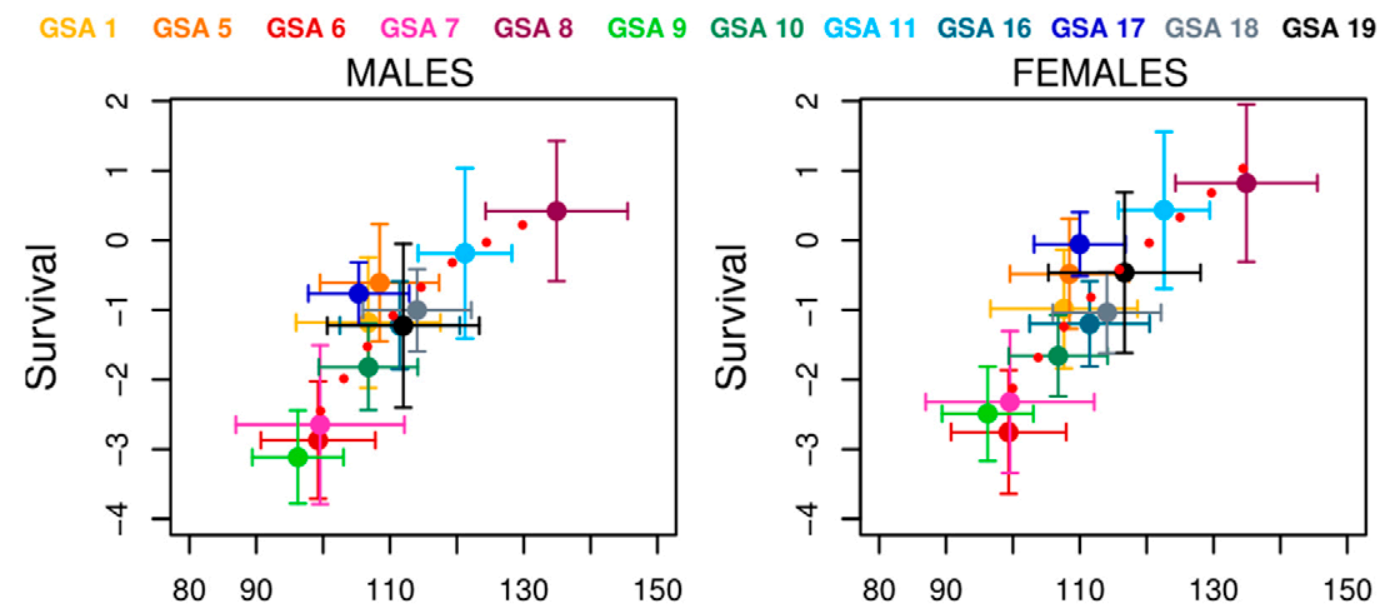

Recruits (t-1) mean length ( $\mathrm{mm}$;

Recruits ( $\mathrm{t}-1)$ mean length $(\mathrm{mm})$
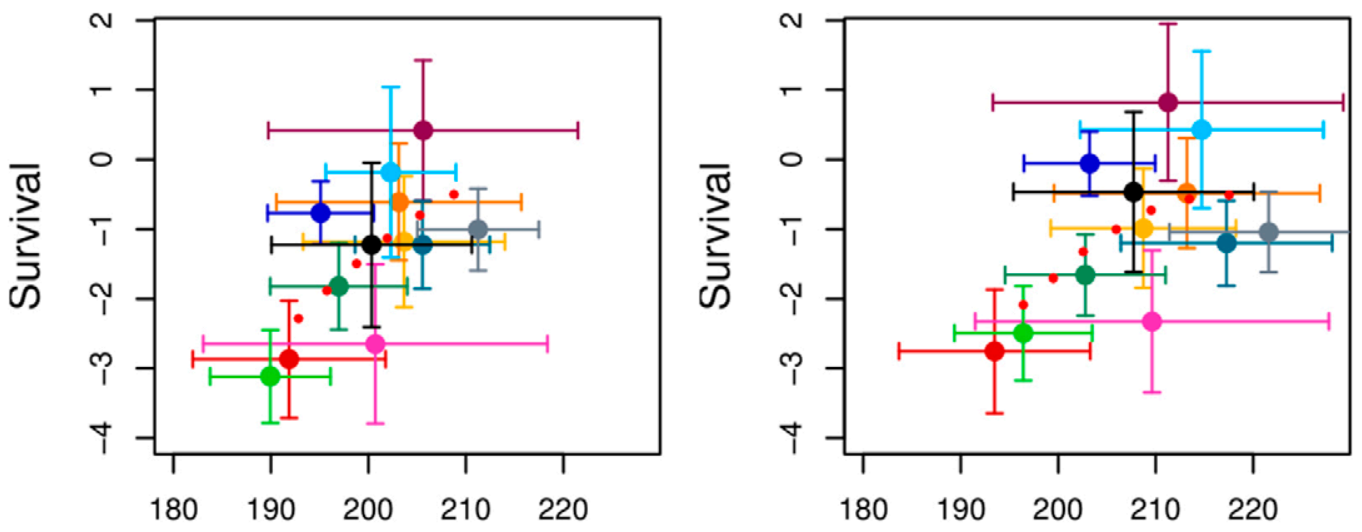

Juveniles (t) mean length ( $\mathrm{mm}$ )

Juveniles (t) mean length ( $\mathrm{mm}$ )
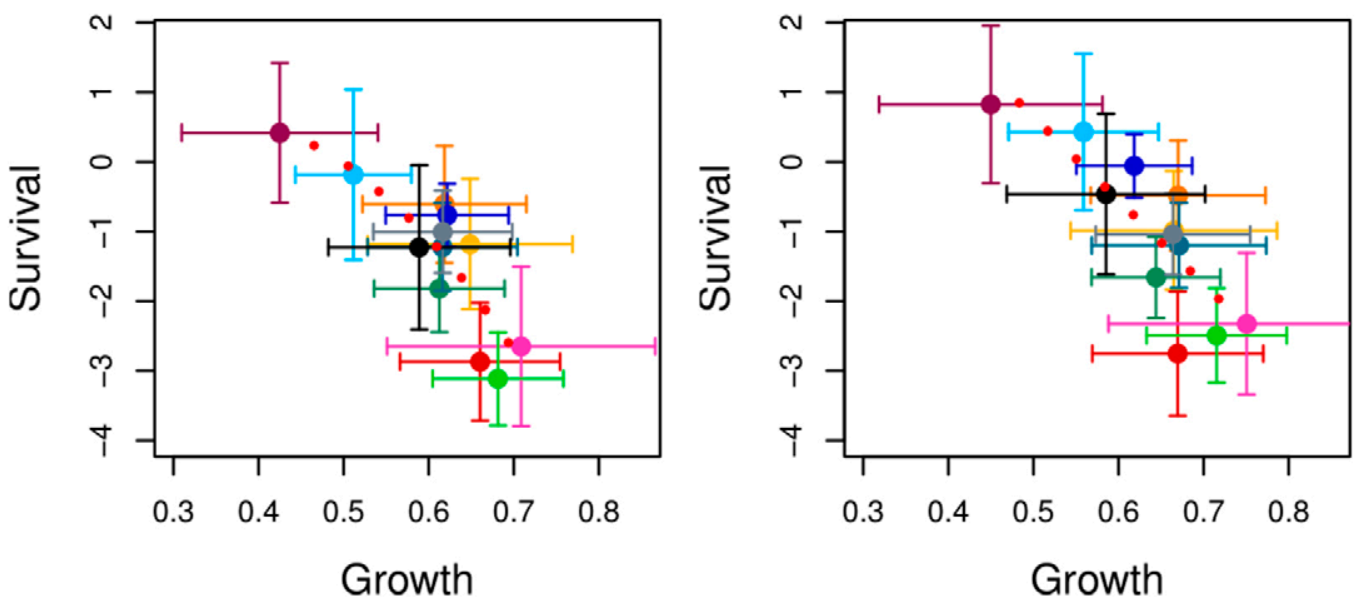

Fig. 5. - Relationships between mean survival and recruit mean length at time $t-1$ (above), juvenile mean length at time $t$ (centre) and growth (bottom) for each GSA (colour codes consistent with Figs. 2 and 3). Male relationships are represented on the left and female relationships on the right. Red dotted lines represent non-linear regression fit using a general additive model - in all the models the covariates showed a significant effect. Bars represent the standard deviation over the whole time series.

While the density-dependent effect on ML of juveniles was generally significant in the central Mediterranean GSAs and non-significant in the western Mediterranean, the density-dependent effect on growth was, in contrast, significant in most areas of the western Mediterranean (Fig. 6).

\section{Drivers of temporal variation of survival for each GSA}

Table 1 shows the best models for juvenile survival of males, females and the combination of both sexes in each GSA. A negative effect of the ML on the juvenile 

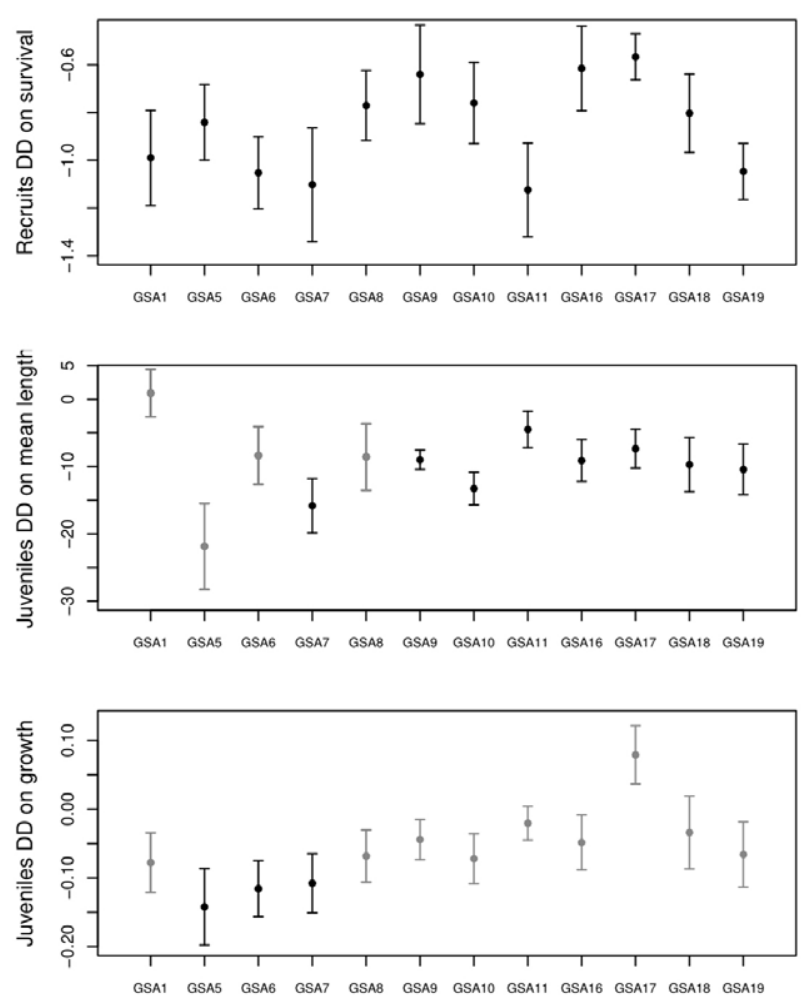

GSA

Fig. 6. - Strength of density dependence plotted as the value of the slope of the relationship with density estimates: density-dependent effect of recruit density on survival (top), density-dependent effect of juvenile density on mean length of juveniles (middle), and growth (bottom). Black symbols represent significant effects $(\mathrm{p}<0.05)$ and grey symbols non-significant effects $(\mathrm{p}>0.05)$.

survival of a given year was the most recurrent pattern observed (GSAs 5, 7, 8, 10 and 16). A negative effect of growth was observed in the western Ionian (GSA19) and northern Spain (GSA-6), while a positive effect of the ML of recruits was observed in the Alboran Sea (GSA-1) and northern Spain. A positive effect of chlorophyll in winter was observed in the Alboran Sea, while a significant negative effect of chlorophyll in spring was observed in the whole Adriatic. A marginal effect of sea surface temperature in spring was observed in female survival in the western Ionian. Figure S2 (Supplementary material) presents the residuals of all the best models included in Table 1 .

The global model, which analyses exclusively the most recurrent covariate (mean length of juveniles, $\mathrm{ML}_{\mathrm{juv}}$ ), showed a clear effect of $\mathrm{ML}_{\mathrm{juv}}$ on male survival, with a significant effect in all the GSAs with the exception of the Alboran Sea (GSA-1) (Fig. 7). This effect was stronger in the Balearic Islands (GSA-5), the Gulf of Lions (GSA-7), eastern Corsica (GSA-8), the Ligurian and northern Tyrrhenian seas (GSA-9), the Strait of Sicily (GSA-16), the northern Adriatic (GSA17) and the western Ionian (GSA-19). In females, the effect was only significant in the Balearic Islands, the Gulf of Lions, the Ligurian and Tyrrhenian seas and the western Ionian. Finally, the negative correlations obtained between the FPIs were not considered of relevance (Supplementari material Fig. S2).

\section{DISCUSSION}

Our study indicates that the spatial and temporal coverage of the MEDITS programme can provide significant insights into the survival of juvenile hake in Mediterranean populations, despite sampling and ecological constraints. These constraints are associated with the seasonality of the information and the consequent lack of information of intra-annual recruitment events occurring later (i.e. autumn) than the period covered by the survey, along with the fast ontogenetic changes in the behaviour of the species. At a basin scale, the results support our expectations with higher survival in areas (i.e. GSAs) with higher ML. However, at an interannual level, the most recurrent pattern contrasts with higher survival at smaller MLs, which may have several explanations (see below). In addition, the results suggest that the relationship between survival and length (and growth) can be indirectly mediated by the strength of the density dependence, at least for the western Mediterranean areas. Finally, important elements of the study are the identification of

Table 1. - Covariates of the best linear models obtained to model juvenile survival as response variables. Models were independently performed for all individuals, males and females for each geographical subarea (GSA) (see Statistical Analyses in the Methods section). As model covariates, Chl-w and Chl-s are respectively chlorophyll in winter and spring; ML rec and ML juv, the mean length in recruits and juveniles respectively; Growth, the differential growth; and SST-s, the mean sea surface temperature in spring. Signs in parenthesis represents the direction of the effect in the response variable. Adjusted $\mathrm{R}^{2}\left(\mathrm{R}^{2}{ }_{\text {adj }}\right)$ for each model is also reported in parenthesis.**, $\mathrm{p}<0.005$; $*, \mathrm{p}<0.05$.

\begin{tabular}{|c|c|c|c|}
\hline Geographic Subarea & All & Males & Females \\
\hline GSA-1 - Northern Alboran & $\begin{array}{c}\text { Chl-w** }(+), \text { ML rec }(\mathrm{t}-1)^{*}(+) \\
\left(\mathrm{R}^{2}{ }_{\mathrm{adj}}=0.64\right)\end{array}$ & $\begin{array}{c}\text { Chl-w** }(+), \text { ML rec }(\mathrm{t}-1)^{*}(+) \\
\left(\mathrm{R}^{2}{ }_{\mathrm{adj}}=0.66\right)\end{array}$ & Chl-w** $(+)\left(\mathrm{R}^{2}{ }_{\mathrm{adj}}=0.46\right)$ \\
\hline GSA-5 - Balearic Islands & $\operatorname{ML}$ juv $(\mathrm{t})^{*}(-)\left(\mathrm{R}_{\mathrm{adj}}^{2}=0.33\right)$ & $\operatorname{ML}$ juv $(\mathrm{t})^{*}(-)\left(\mathrm{R}_{\text {adj }}^{2}=0.35\right)$ & - \\
\hline GSA-6 - Northern Spain & ML rec $(\mathrm{t}-1)^{*}(+)\left(\mathrm{R}_{\mathrm{adj}}^{2}=0.23\right)$ & Growth* $(-)\left(\mathrm{R}_{\mathrm{adj}}^{2}=0.25\right)$ & Growth* $(-)\left(\mathrm{R}_{\mathrm{adj}}^{2}=0.22\right)$ \\
\hline GSA-7 - Gulf of Lion & $\operatorname{ML}$ juv $(\mathrm{t}) * *(-)\left(\mathrm{R}_{\mathrm{adj}}^{2}=0.32\right)$ & $\operatorname{ML~juv~}(\mathrm{t})^{* *}(-)\left(\mathrm{R}_{\mathrm{adj}}^{2}=0.25\right)$ & $\operatorname{ML~juv~}(\mathrm{t})^{* *}(-)\left(\mathrm{R}_{\text {adj }}^{2}=0.38\right)$ \\
\hline GSA-8 - Corsica & - & $\operatorname{ML}$ juv $(\mathrm{t}) * *(-)\left(\mathrm{R}_{\mathrm{adj}}^{2}=0.28\right)$ & - \\
\hline GSA-9 - Ligurian-North Tyrrhenian & - & - & $\operatorname{ML}$ juv $(\mathrm{t}) *(-)\left(\mathrm{R}_{\mathrm{adj}}^{2}=0.19\right)$ \\
\hline GSA-10 - South-Cenrtral Tyrrhenian & $\operatorname{ML~juv~(t)**(-)~}\left(\mathrm{R}^{2}{ }_{\mathrm{adj}}=0.39\right)$ & $\operatorname{ML~juv~}(\mathrm{t}) * *(-)\left(\mathrm{R}^{2}{ }_{\mathrm{adj}}=0.38\right)$ & $\operatorname{ML~juv~}(\mathrm{t})^{* *}(-)\left(\mathrm{R}_{\mathrm{adj}}^{2}=0.34\right)$ \\
\hline GSA-11 - Sardinia & - & - & - \\
\hline GSA-16 - South Sicily & $\operatorname{ML~juv~}(\mathrm{t})^{*}(-)\left(\mathrm{R}_{\mathrm{adj}}^{2}=0.19\right)$ & $\operatorname{ML}$ juv $(\mathrm{t}) * *(-)\left(\mathrm{R}_{\mathrm{adj}}^{2}=0.29\right)$ & - \\
\hline GSA-17 - Northern Adriatic & Chl-s* $(-)\left(\mathrm{R}_{\mathrm{adj}}^{2}=0.25\right)$ & Chl-s* (-) $\left(\mathrm{R}_{\mathrm{adj}}^{2}=0.25\right)$ & Chl-s* (-) $\left(\mathrm{R}_{\text {adj }}^{2}=0.24\right)$ \\
\hline GSA-18 - Southern Adriatic & Chl-s* $(-)\left(\mathrm{R}_{\mathrm{adj}}^{2}=0.25\right)$ & Chl-s* $(-)\left(\mathrm{R}_{\mathrm{adj}}^{2}=0.25\right)$ & Chl-s* $(-)\left(\mathrm{R}_{\mathrm{adj}}^{2}=0.24\right)$ \\
\hline GSA-19 - Western Ionian & Growth* $(-)\left(\mathrm{R}^{2}{ }_{\text {adj }}=0.22\right)$ & Growth* $(-)\left(\mathrm{R}^{2}{ }_{\text {adj }}=0.28\right)$ & - \\
\hline
\end{tabular}


MALES

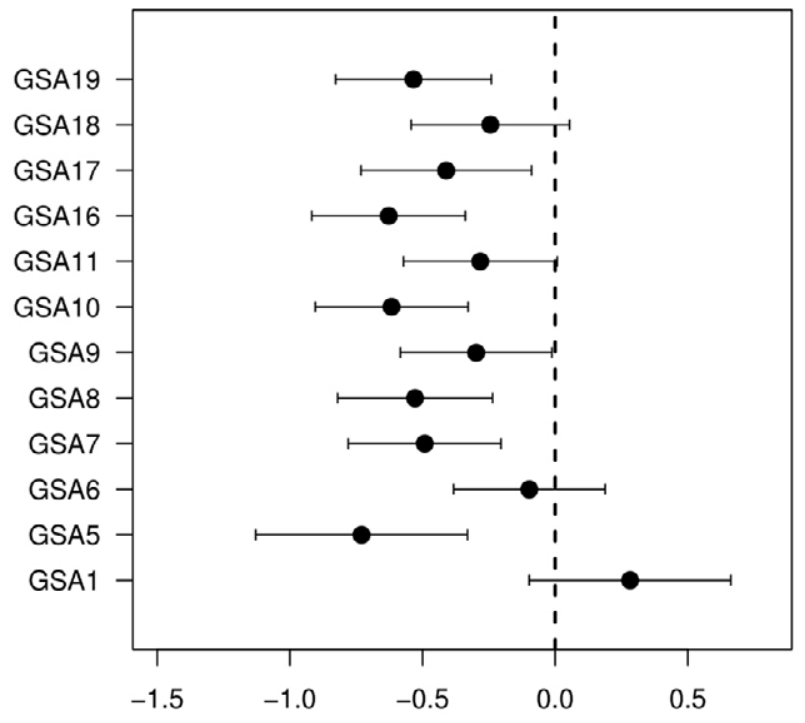

Standarized Juv. Mean length effect
FEMALES

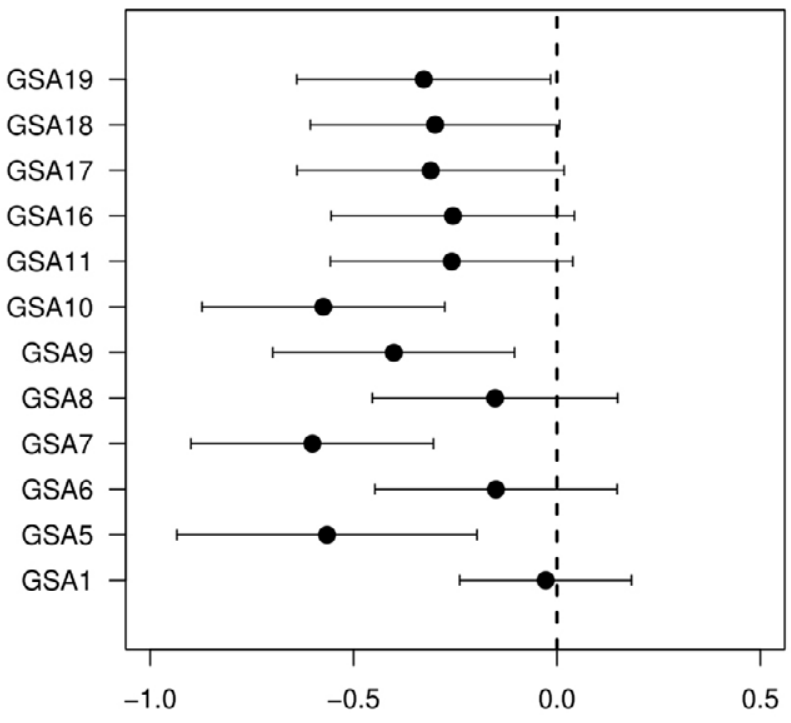

Standarized Juv. Mean length effect

Fig. 7. - Size of effect of juvenile mean length on juvenile survival (male model on the left and female model on the right) for each GSA, applying a linear model to the standardized variables (mean 0 and variance 1). No overlapping of horizontal bars (standard error of the model estimates) with zero vertical lines reveals statistical significance of the effect.

areas with hake survival that is highly sensitive to primary production variability, such as the Alboran and Adriatic seas, and areas with positive survival values that could indicate movement of recruits and juvenile fish to these areas (i.e. eastern Corsica and Sardinia) or strong intra-annual recruitment events later in the year that were not detected during the survey. In general, analyses performed by sex provided the same message.

Although there is no geographical segregation in the mean patterns, survival and growth time series in the western areas (from the Alboran Sea, GSA-1, to Sardinia, GSA 11) show a more fluctuating and variable pattern both at an interannual scale and between areas. This may indicate a more complex combination of environmental and ecological processes, but also a more heterogeneous effect of fishing. In contrast, in the central areas (from the Strait of Sicily, GSA-16, to the western Ionian, GSA-19), the fluctuation pattern is greatly reduced for both survival and growth. The geographical pattern of mean survival reveals that the areas with higher ML of recruits are consistent with those of higher ML of juveniles, yielding higher survival. This finding suggests a fast-growth pattern during the pre-recruitment to fishery stages (first six months of life, including early life stages, bottom settlement and arrival at the nursery areas) that has been shown to lead to size-selective processes, as pre-recruits spend less time in smaller size classes, which are more vulnerable to predation (e.g. Houde 1997, Sogard 1997, Conover 2007). This pattern can be additionally affected by geographical differences in the bottom settlement peak. The opposite relationship observed between juvenile growth and survival must represent the 'compensatory growth', an ecological strategy observed in several species in which high energetic investment in the growth rates during the first year to maximize survival is com- pensated with reduced growth in the second year of life (Sogard 1997, Ali et al. 2003). Under this strategy, fish allocate energy preferentially to increase protein before lipids are restored (Schultz and Conover 1997), and was already suggested for hake in the Mediterranean Sea as a mechanism for maximizing recruitment in populations that are highly dependent on recruitment success (Hidalgo et al. 2009).

The analyses at temporal scale of all GSAs show a negative effect of ML of juveniles, with higher survival at lower lengths - an opposite pattern to that observed at biogeographical scale. While this response seems counterintuitive a priori, it has previously been observed in analyses of juvenile survival using information of seasonal scientific surveys (Ciannelli et al. 2007). Ciannelli et al. (2007) reported a similar pattern in pollock juvenile survival and argued a potential under-representation of larger and older juvenile fish. The ontogenetic changes in catchability have been demonstrated to be progressive and often with nonlinear forms that maximize catchability in juvenile stages, as has been observed in several gadoid species, including hake (Fraser et al. 2007). This means that escapement capabilities and aggregation behaviour of juvenile hakes around $20 \mathrm{~cm}$ are not the same as those of larger individuals of the same age class, i.e. close to 30 cm (Mahévas et al. 2011): this decrease in catchability with size could partially affect the juvenile stage. In addition, the lack of information of cohorts (intra-annual recruitment events) recruiting to the nursery grounds after the survey (late summer or autumn) could also affect survival estimates. Although spring-early summer is the seasonal window for the main recruitment peak over the whole Mediterranean (Druon et al. 2015 and references therein), several intra-annual recruitment events have been reported in the Mediterranean in cer- 
tain areas (e.g. Arneri and Morales-Nin 2000, Rey and Gil de Sola 2004, Belcari et al. 2006). Thus, a certain amount of recruits of secondary intra-annual recruitment events that are not captured in a given year could be captured as juveniles the year after.

In addition to this general pattern, our analyses also indicate a positive effect of recruit length and a negative effect of juvenile growth on survival in the Alboran Sea (GSA-1), northern Spain (GSA-6) and western Ionian Sea (GSA-19). This finding evidences a sizedependent mortality shaping the regional population dynamics of hake for these areas, similarly to what has been observed in other species (Lorenzen and Enberg 2002). In addition, the significant density-dependent effect on growth observed in the western Mediterranean areas provides an additional element of the indirect influence of growth on survival, as growth limitation under high densities can be linked to competition and mortality related to food limitation (Le Pape and Bonhommeau et al. 2015). This is also in agreement with a recent theoretical framework by Andersen et al. (2017), who argue that, in habitats of small and medium size, density-dependent regulation of populations does not occur only in early life stages, but also late during life. Andersen et al. (2017) show that competition in the juvenile stages may lead to stunted growth, as we here observe in hake, and to overcompensation regulation of the populations at small scales. This finding underlines the fact that density dependence in marine fish population is more complex than can be captured by models of spatially homogeneous population dynamics or by models based on stock-recruitment relationships.

Our results show two areas (the Alboran and Adriatic seas) in which survival of juveniles is strongly controlled by environmental variability, and particularly by primary production. However, the season of the environmental effect differs in the two regions and the direction of the effect appears to be opposite. In the Alboran Sea, the increase in primary production due to the influence of the Atlantic inflow and the meandering and mesoscale circulation is known to fuel the whole trophic chain (Oguz et al. 2014). In winter, this oceanographic scenario impacts the recruitment dynamics of several species in the Alboran Sea (Catalán et al. 2013, Ruiz et al. 2013), and is consistent with our results suggesting more food availability that favours hake survival. By contrast, survival in the Adriatic Sea is negatively correlated with strength of primary production in spring. This negative relationship between primary production and marine resources production has already been observed in the Mediterranean and attributed to inter-specific competition (Puerta et al. 2015). Thus, we could interpret that years with high productivity in the Adriatic in spring increase the overall abundance of the nektobenthic community, increasing the competition between hake and other species that may trigger food limitation and low survival (or active movements of hake juveniles to other areas with less competition).

It is worth noting that eastern Corsica and Sardinia (and, to a lesser degree, western Ionian) show many years with positive survival values (more juveniles than recruits the year before), with no clear temporal trend. In addition to the potential influence of late-inyear recruitment pulses discussed above, another plausible explanation is that this pattern is a consequence of an active movement of recruits and juveniles from neighbouring areas. The high ML values of recruits for these two areas (eastern Corsica and Sardinia) support this hypothesis, suggesting that this active feeding migration could start during the second year of life of the species, once the ontogenetic bathymetric migration is finished. Although bathymetric migrations of juvenile hake have been described as part of the ontogenetic changes in habitat selection for this species (Bartolino et al. 2008b, Hidalgo et al. 2008), they are compatible with potential geographic juvenile feeding migrations in the Mediterranean to neighbouring geographic subareas. Active migratory movements across management areas have been evidenced for the Atlantic hake stocks (Pita et al. 2016), whose habitats are considerably larger than those in the Mediterranean and those of other hake species worldwide (e.g. Agostini et al. 2006), suggesting that this may also happen in the Mediterranean. This would provide an additional element for the consideration of transboundary assessment of hake in certain regions of the Mediterranean Sea beyond the geographical limits of the GSAs (e.g. Fiorentino et al. 2014, STECF 2015, among others, see below). However, the hypothesis of transboundary feeding migration certainly requires additional research using complementary and additional data in order to be well supported.

\section{Fishing impact, assessment and management implications}

Improving knowledge of the distribution and abundance patterns of exploited resources is a key element for offering better advice for fishing management. Doing so requires increasing the knowledge on life stages sensitive to climate forcing or fishing impact, such as recruits and juveniles of hake, for which conservative management measures play an important role in the Mediterranean Sea. Although we did not detect a robust sign of fishing impact in this study, the influence of fishing activity cannot be disregarded, as hake trawl fisheries in the Mediterranean Sea are mainly sustained by the exploitation of juveniles (Colloca et al. 2013, Ligas et al. 2015, STECF 2015). For stock assessment purposes, a correct computation of mortality rates, considering both fishing mortality and natural mortality, is essential. The modelling of juvenile harvest and how to estimate and implement realistic vectors of natural mortality in the assessment and management of this species have been important topics of research in the last two decades (e.g. Abella et al. 1997, Caddy and Abella 1999, Caddy 2015). To this end, scientificallybased information is required to disentangle ecological processes that affect their survival (i.e. natural mortality) from those that can be spatially and/or temporally managed (i.e. fishing mortality). The present study provides new insights into these challenges and into the integration of ecological processes affecting hake 
survival in a more holistic assessment of this species towards the operationalization and implementation of the ecosystem approach to fisheries (Link and Browman 2017). New generation fisheries assessment may also reflect the increasing importance of the structural complexity of populations and the heterogeneity of processes at regional scale: habitat selection, density dependence, (passive) connectivity or active movements/ migrations. Although the first exercises of assessments combining several GSAs have been already carried out by STECF and GFCM WGs since 2015 (e.g. GSA 1-7; GSA 9-10-11; GSA 17-18; STECF 2015, GFCM 2016), these combinations are supported by evolutionary connectivity (i.e. absence of genetic differences), and few of them support demographic connectivity (i.e. effective number of individuals exchange at interannual scale between close sub-populations). The spatial scale of management can be different to the spatial scale of the assessment (Cadrin and Secor 2009), and neighbouring areas must be combined only if they demographically interact at an interannual scale and the cross-boundary movement of individuals impacts the population dynamics principles (and equations) that sustain fisheries assessment methods (Kerr et al. 2017, Goethel et al. 2017).

From the spatial management perspective (i.e. marine spatial planning), and its application to fisheries, the present study provides useful insights for implementing marine spatial planning in fisheries management in close communication with temporal fisheries assessment. As natural populations are highly dynamic in space and time, there is an increased need to include such spatiotemporal transboundary scenarios in a more flexible and adaptive fishing management (e.g. fisheries restricted areas or marine protected areas). For instance, management measures such as the recent protection of essential fish habitats for recruitment for hake and shrimps in the central Mediterranean (Strait of Sicily, Vielmini et al. 2017) must be further expanded to the whole Mediterranean basin.

In addition, European fisheries are transitioning to new rules aimed at reducing discards and mandatorily bringing all catches to land (the "discard ban" or "landing obligation": Art. 15 of the new Common Fisheries Policy, Reg. EU No 1380/2013). These new rules are likely to affect fishery activities in Europe. As it is impossible to completely avoid unwanted catches, and the Common Fisheries Policy will progressively phase out discards of regulated species (i.e. those subject to quotas and species with a minimum conservation reference size in the Mediterranean; see Reg. EC No 1967/2006), it is essential to know the spatial patterns of the juvenile stage to characterize areas that may have high quantities and persistence of unwanted catches (Paradinas et al. 2016, Maeda et al. 2017, Pennino et al. 2017).

All these elements are well framed in the essence of the Mid-Term Strategy 2017-2020 (MTS, Resolution GFCM/40/2016/2) launched by the GFCM to implement new fisheries governance in the Mediterranean Sea and to ensure the conservation and sustainable exploitation of living marine resources while protecting habitats and vulnerable species from fishing. Indeed, the results of the present study may contribute to two of the five structured targets of the MST: i) reverse the declining trend of fish stocks through strengthened scientific advice in support of management, and ii) minimize and mitigate unwanted interactions between fisheries and marine ecosystems and environment. The present study provides information to improve the quantification of the survival in the recruit and juvenile stages of hake, which are the stages most harvested by commercial fleets, especially bottom trawlers. Our study also highlights the importance of size- and growth-dependent survival in the juvenile stages of hake in the Mediterranean Sea and the contribution that scientific surveys can regularly make to the understanding of these processes.

\section{ACKNOWLEDGEMENTS}

We thank all the dedicated people who have worked since 1994 on the research and fishing vessels conducting the MEDITS surveys throughout the Mediterranean Sea. MEDITS data were co-funded by the EU through the European Maritime and Fisheries Fund (EMFF) within the national programme of collection, management and use of data in the fisheries sector and support for scientific advice regarding the Common Fisheries Policy. MH also thanks P. Tugores for her help on the mapping and coding.

\section{REFERENCES}

Abella A.J., Caddy J.F., Serena F. 1997. Do natural mortality and availability decline with age? An alternative yield paradigm for juvenile fisheries, illustrated by the hake Merluccius merluccius fishery in the Mediterranean. Aquat. Living Res. 10: 257-269. https://doi.org/10.1051/alr:1997029

Abella A.J, Serena F., Ria M. 2005. Distributional response to variations in abundance over spatial and temporal scales for juveniles of European hake (Merluccius merluccius) in the Western Mediterranean Sea. Fish. Res. 71: 295-310. https://doi.org/10.1016/j.fishres.2004.08.036

Agostini V.N., Francis R.C., Hollowed A.B. et al. 2006. The relationship between Pacific hake (Merluccius productus) distribution and poleward subsurface flow in the California Current System. Can. J. Fish. Aquat. Sci. 63: 2648-2659. https://doi.org/10.1139/f06-139

Ali M., Nicieza A., Wootton R.J. 2003. Compensatory growth in fishes: a response to growth depression. Fish Fish. 4: 147-190. https://doi.org/10.1046/j.1467-2979.2003.00120.x

Aldebert Y., Recasens L., Lleonart J. 1993. Analysis of gear interactions in a hake fishery: the case of the Gulf of Lions (NW Mediterranean). Sci. Mar. 57: 207-217.

Andersen H. Jacobsen N.S., Jansen T. et al. 2017. When in life does density dependence occur in fish populations? Fish Fish. 18: 656-667. https://doi.org/10.1111/faf.12195

Anonymous 2017. MEDITS-Handbook. Version n. 9, MEDITS Working Group, 106 pp. http://www.sibm.it/MEDITS\%202011/principaledownload. htm</ext-link $>$

Arneri E., Morales-Nin B. 2000. Aspects of the early life history of European hake from the central Adriatic. J. Fish Biol. 56: 1368-1380. https://doi.org/10.1111/j.1095-8649.2000.tb02149.x

Bartolino V., Colloca F., Sartor P., et al. 2008a. Modelling recruitment dynamics of hake, Merluccius merluccius, in the central Mediterranean in relation to key environmental variables. Fish. Res. 93: 277-288. https://doi.org/10.1016/j.fishres.2008.01.007

Bartolino V., Ottavi A., Colloca F. et al. 2008b. Bathymetric preferences of juvenile European hake (Merluccius merluccius). 
ICES J Mar. Sci. 65: 963-969.

https://doi.org/10.1093/icesjms/fsn079

Baudron A.R., Fernandes P.G. 2015. Adverse consequences of stock recovery: European hake, a new "choke" species under a discard ban? Fish Fish. 16: 563-575.

https://doi.org/10.1111/faf.12079

Belcari P., Ligas A., Viva C. 2006. Age determination and growth of juveniles of the European hake, Merluccius merluccius (L., 1758), in the northern Tyrrhenian Sea (NW Mediterranean). Fish. Res. 78: 211-217. https://doi.org/10.1016/j.fishres.2006.01.006

Bertrand J.A., Gil de Sola L., Papaconstantinou C et al. 2002. The general specifications of the MEDITS surveys. Sci. Mar. 66: 9-17. https://doi.org/10.3989/scimar.2002.66s29

Caddy J.F. 2015. Criteria for sustainable fisheries on juveniles illustrated for Mediterranean hake: control the juvenile harvest, and safeguard spawning refugia to rebuild population fecundity. Sci. Mar. 79(3): 287-299. https://doi.org/10.3989/scimar.04230.06A

Caddy J.F., Abella A.J. 1999. Reconstructing reciprocal M vectors from length cohort analysis (LCA) of commercial size frequencies of hake, and fine mesh trawl surveys over the same grounds. Fish. Res. 41: 169-175. https://doi.org/10.1016/S0165-7836(99)00015-6

Cadrin S., Secor D. 2009. Accounting for spatial population structure in stock assessment: past, present, and future. In: Beamish R., Rothschild B. (eds), The Future of Fisheries Science in North America. Springer Publishing, Dordrecht, pp. 405-426. https://doi.org/10.1007/978-1-4020-9210-7_22

Cantafaro A., Ardizzone G., Enea M. et al. 2017. Assessing the importance of nursery areas of European hake (Merluccius merluccius) using a body condition index. Ecol. Indic. 81: 383-389. https://doi.org/10.1016/j.ecolind.2017.06.012

Catalán I.A., Macías D., Solé J. et al. 2013. Stay off the motorway: resolving the pre-recruitment life history dynamics of the European anchovy in the SW Mediterranean through a spatiallyexplicit individual-based model (SEIBM). Progr. Oceanog. 111: $140-153$ https://doi.org/10.1016/j.pocean.2013.02.001

Ciannelli L., Dingsør G.E., Bogstad O. et al. 2007. Spatial anatomy of species survival: effects of predation and climate-driven environmental variability. Ecology 88: 635-646. https://doi.org/10.1890/05-2035

Colloca F., Bartolino V., Lasinio G.J. et al. 2009. Identifying fish nurseries using density and persistence measures. Mar. Ecol. Progr. Ser. 381: 287-296. https://doi.org/10.3354/meps07942

Colloca F., Cardinale M., Maynou F., et al. 2013. Rebuilding Mediterranean fisheries: a new paradigm for ecological sustainability. Fish Fish. 14: 89-109. https://doi.org/10.1111/j.1467-2979.2011.00453.x

Conover D.O. 2007. Nets versus nature. Nature 450: 179-180. https://doi.org/10.1038/450179a

Cormon X., Loots C., Vaz S. et al. 2014. Spatial interactions between saithe (Pollachius virens) and hake (Merluccius merluccius) in the North Sea. ICES J. Mar. Sci. 71: 1342-1355. https://doi.org/10.1093/icesjms/fsu120

Druon J.N., Fiorentino F., Murenu M., et al. 2015. Modelling of European hake nurseries in the Mediterranean Sea: An ecological niche approach. Progr. Oceanogr. 130: 188-204. https://doi.org/10.1016/j.pocean.2014.11.005

Fernandes P.G., Ralph G.M., Nieto A. et al. 2017. Coherent assessments of Europe's marine fishes show regional divergence and megafauna loss. Nat. Ecol. Evol. 1: 0170. https://doi.org/10.1038/s41559-017-0170

Ferraton F., Harmelin-Vivien M., Mellon-Duval C. et al. 2007. Spatio-temporal variation in diet may affect condition and abundance of juvenile European hake in the Gulf of Lions (NW Mediterranean). Mar. Ecol. Progr. Ser. 337: 197-208. https://doi.org/10.3354/meps337197

Fiorentino F., Massutí E., Tinti S. et al. 2014. Stock units: Identification of distinct biological units (stock units) for different fish and shellfish species and among different GFCM-GSA. STOCKMED Deliverable 03: FINAL REPORT. September 2014, 310 pp.

Fraser H.M., Greenstreet S.P.R., Piet G.J. 2007. Taking account of catchability in groundfish survey trawls: implications for estimating demersal fish biomass. ICES J. Mar. Sci. 64: 1800-1819. https://doi.org/10.1093/icesjms/fsm145
García-Rodriguez M., Esteban A. 2002. How fast does hake grow? A study on the Mediterranean hake (Merluccius merluccius L.) comparing whole otoliths readings and length frequency distributions data. Sci. Mar. 66: 145-156. https://doi.org/10.3989/scimar.2002.66n2145

GFCM. 2016. Working Group on Stock Assessment of Demersal Species (WGSAD). GFCM and FAO headquarters, Rome, Italy, 7-12 November 2016. Final Report. 74 pp.

Goethel D.R., Berger A.M. 2017. Accounting for spatial complexities in the calculation of biological reference points: effects of misdiagnosing population structure for stock status indicators. Can. J. Fish. Aquat. Sci. 74: 1878-1894. https://doi.org/10.1139/cjfas-2016-0290

Hidalgo M., Massutí E., Moranta J. et al. 2008. Seasonal and short spatial patterns in European hake (Merluccius merluccius L.) recruitment process at the Balearic Islands (western Mediterranean): the role of environment on distribution and condition. J. Mar. Syst. 71: 367-384 https://doi.org/10.1016/j.jmarsys.2007.03.005

Hidalgo M., Tomas J., Moranta J. et al. 2009. Intra-annual recruitment events of a shelf species around an island system in the NW Mediterranean. Est. Coast. Shelf Sci. 83: 227-238. https://doi.org/10.1016/j.ecss.2009.03.037

Hidalgo M., Rouyer T., Molinero J. C, et al. 2011. Synergistic effects of fishing-induced demographic changes and climate variation on fish population dynamics. Mar. Ecol. Prog. Ser. 426: $1-12$. https://doi.org/10.3354/meps09077

Hidalgo M., Olsen E.M., Ohlberger J. et al. 2014. Contrasting evolutionary demography induced by fishing: the role of adaptive phenotypic plasticity. Ecol. Applic. 24: 1101-1114. https://doi.org/10.1890/12-1777.1

Houde E.D. 1997. Patterns and consequences of selective processes in teleost early life histories. In: Chambers R.C. and Trippel E.A. (eds), Early Life History and Recruitment in Fish Populations. Chapman \& Hall Fish and Fish. Series, vol 21. Springer, Dordrecht https://doi.org/10.1007/978-94-009-1439-1_6

Kavadas S., Maina I., Damalas, D. et al. 2015. Multi-Criteria Decision Analysis as a tool to extract fishing footprints: application to small scale fisheries and implications for management in the context of the Maritime Spatial Planning Directive. Medit. Mar. Sci. 16: 294-304. https://doi.org/10.12681/mms.1087

Kerr L.A., Hintzen N.T., Cadrin S.X. et al. 2017. Lessons learned from practical approaches to reconcile mismatches between biological population structure and stock units of marine fish. ICES J. Mar. Sci. 74: 1708-1722. https://doi.org/10.1093/icesjms/fsw188

Jørgensen C., Holt R.E. 2013. Natural mortality: Its ecology, how it shapes fish life histories, and why it may be increased by fishing. J. Sea Res. 75: 8-18. https://doi.org/10.1016/j.seares.2012.04.003

Le Pape O., Bonhommeau S. 2015. The food limitation hypothesis for juvenile marine fish. Fish Fish. 16: 373-398. https://doi.org/10.1111/faf.12063

Lembo G., Silecchia T., Carbonara P., et al. 2000. Nursery areas of Merluccius merluccius in the Italian Seas and in the East Side of the Adriatic Sea. Biol. Mar. Medit. 7: 98-116.

Levin P.S., Stunz G.W. 2005. Habitat triage for exploited fishes: Can we identify essential "Essential Fish Habitat"? Est. Coast. Shelf Sci. 64: 70-78. https://doi.org/10.1016/j.ecss.2005.02.007

Ligas A., Colloca F., Lundy M.G. et al. 2015. Modeling the growth of recruits of European hake (Merluccius merluccius) in the northwestern Mediterranean Sea with generalized additive models. Fish. Bull. 113: 69-82. https://doi.org/10.7755/FB.113.1.7

Link J. S., Browman H.I. 2017. Operationalizing and implementing ecosystem-based management. ICES J. Mar. Sci. 74: 379-381. https://doi.org/10.1093/icesjms/fsw247

Lorenzen K., Enberg K. 2002. Density-dependent growth as a key mechanism in the regulation of fish populations: evidence from among-population comparisons. Proc. R. Soc. Lon. B Biol. Sci. 269: 49-54 https://doi.org/10.1098/rspb.2001.1853

Maeda E.E., Mäntyniemi S., Despoti S. et al. 2017. A Bayesian model of fisheries discards with flexible structure and priors defined by experts. Ecol. Mod. 366: 1-14. https://doi.org/10.1016/j.ecolmodel.2017.10.007 
Mahévas S., Trenkel V.M., Doray M. 2011. Hake catchability by the French trawler fleet in the Bay of Biscay: estimating techni$\mathrm{cal}$ and biological components. ICES J. Mar. Sci. 68: 107-118. https://doi.org/10.1093/icesjms/fsq140

Mellon-Duval C., De Pontual H., Métral L. et al. 2010. Growth of European hake (Merluccius merluccius) in the Gulf of Lions based on conventional tagging. ICES J. Mar. Sci. 67: 62-70. https://doi.org/10.1093/icesjms/fsp215

Morales-Nin B., Moranta J. 2004. Recruitment and post-settlement growth of juvenile Merluccius merluccius on the western Mediterranean shelf. Sci. Mar. 68: 399-409. https://doi.org/10.3989/scimar.2004.68n3399

Oguz T., Macias D., Garcia-Lafuente J.et al. 2014. Fueling plankton production by a meandering frontal jet: a case study for the Alboran Sea (Western Mediterranean). PloS ONE 9: e111482. https://doi.org/10.1371/journal.pone.0111482

Paradinas I., Martín M., Pennino M.G. et al. 2016. Identifying the best fishing-suitable areas under the new European discard ban. ICES J. Mar. Sci. 73: 2479-2487. https://doi.org/10.1093/icesjms/fsw114

Pennino M.G., Vilela R., Valeiras J. et al. 2017. Discard management: A spatial multi-criteria approach. Mar. Policy 77: 144-151. https://doi.org/10.1016/j.marpol.2016.12.022

Pita A., Leal A., Santafé-Muñoz A., et al. 2016. Genetic inference of demographic connectivity in the Atlantic European hake metapopulation (Merluccius merluccius) over a spatio-temporal framework. Fish. Res. 179: 291-301. https://doi.org/10.1016/j.fishres.2016.03.017

Puerta P., Hidalgo M., González M., et al. 2014. Role of hydroclimatic and demographic processes on the spatio-temporal distribution of cephalopods in the western Mediterranean. Mar. Ecol. Prog. Ser. 514: 105-118. https://doi.org/10.3354/meps10972

Puerta P., Hunsicker M.E., Quetglas A. et al. 2015. Spatially explicit modeling reveals cephalopod distributions match contrasting trophic pathways in the western Mediterranean Sea. PloS ONE 10: $\mathrm{e} 0133439$. https://doi.org/10.1371/journal.pone.0133439

Recasens L., Chiericoni V., Belcari P. 2008. Spawning pattern and batch fecundity of the European hake (Merluccius merluccius (Linnaeus, 1758)) in the western Mediterranean. Sci. Mar. 72: 721-732. https://doi.org/10.3989/scimar.2008.72n4721

Rey J., Árbol J., Gil de Sola L. 2004. Seasonal recruitment of hake in the Alboran Sea (SW Mediterranean). Rapp. Comm. Int. Mer Medit. 37: 427

Rueda L., Massutí E., Alvarez-Berastegui D. et al. 2015. Effect of intra-specific competition, surface chlorophyll and fishing on spatial variation of gadoid's body condition. Ecosphere 6: 1-17. https://doi.org/10.1890/ES15-00087.1

Ruiz J., Macias D., Rincon M.M. et al. 2013. Atlantic inflow controls fish recruitment at the Western Mediterranean. Rapp. Comm. Int. Mer Medit. 40: 158.

Sbrana M., Belcari P., De Ranieri S. et al. 2007. Comparison of the catches of European hake (Merluccius merluccius, L. 1758) taken with experimental gillnets of different mesh sizes in the northern Tyrrhenian Sea (Western Mediterranean). Sci. Mar. 71: 47-56.

https://doi.org/10.3989/scimar.2007.71n147

Scientific, Technical and Economic Committee for Fisheries (STECF). 2015. Mediterranean assessments part 1 (STECF-15-18). Publ. Off. Europ. Union, Luxembourg, EUR 27638 EN, JRC 98676, 410 pp.

Schultz E.T., Conover D.O. 1997. Latitudinal differences in somatic energy storage: adaptive responses to seasonality in an estuarine fish (Atherinidae: Menidia menidia). Oecologia 109: 516-529. https://doi.org/10.1007/s004420050112

Sogard S.M. 1997. Size-selective mortality in the juvenile stage of teleost fishes: a review. Bull. Mar. Sci. 60: 1129-1157.

Souplet A. 1996. Calculation of abundance indices and length frequencies in the MEDITS survey. In: Bertrand J.A. et al. (eds), Campagne internationale du chalutage démersal en Méditerraneé. Campagne 1995. EU Final Report, Vol. III.

Suthers I.M. 1998. Bigger? Fatter? Or is faster growth better? Considerations on condition in larval and juvenile coral-reef fish. Austral Ecol. 23: 265-273. https://doi.org/10.1111/j.1442-9993.1998.tb00730.x

Vasilakopoulos P., Maravelias C.D., Tserpes G. 2014. The alarming decline of Mediterranean fish stocks. Curr. Biol. 24: 1643-1648. https://doi.org/10.1016/j.cub.2014.05.070

Vielmini I., Perry A.L., Cornax M.J. 2017. Untying the Mediterranean Gordian knot: a twenty first century challenge for fisheries management. Front. Mar. Sci. 4: 195 https://doi.org/10.3389/fmars.2017.00195

\section{SUPPLEMENTARY MATERIAL}

The following supplementary material is available through the online version of this article and at the following link:

http://scimar.icm.csic.es/scimar/supplm/sm04857esm.pdf

Material and methods supplementary text.

Table S1. - Ranking of the criteria taken into account in MCDA per length overall (LOA) segmentation. The higher the grade, the more favourable the area is for trawl fishing activities.

Fig. S1. - Model residuals against response variable for the best linear model obtained for each GSA (Table 1) for all individuals (left), males (centre) and females (right). Here, models for GSA-1, GSA-5, GSA-6 and GSA-7 are shown.

Fig. S2. - Scatter plot of the residuals of the global survival model for females applying a linear model on the standardized variables (mean 0 and variance 1 ) and the fishing pressure indicator for 1994 (left), 2004 (centre) and 2014 (right). While the negative correlations obtained between the fishing pressure indices and the residuals of the global model were very low $(-0.23<$ rho $\leq 0.17$, right $)$, those correlations for females were relatively high $(-0.62<$ rho $\leq 0.60$, left $)$. However, these high correlation values are forced by two extreme values of FPI: the lowest in the Balearic Islands (GSA-5) and the highest in the northern Adriatic (GSA-17). 


\section{Size-dependent survival of European hake juveniles in the Mediterranean Sea}

Manuel Hidalgo, Alessandro Ligas, José María Bellido, Isabella Bitetto, Pierluiggi Carbonara, Roberto Carlucci, Beatriz Guijarro, Angelique Jadaud, Giuseppe Lembo, Chiara Manfredi, Antonio Esteban, Germana Garofalo, Zdravko Ikica, Cristina García, Luis Gil de Sola, Stefanos Kavadas, Irida Maina, Letizia Sion, Stefania Vittori, Nedo Vrgoc

Supplementary material 


\section{MATERIAL AND METHODS SUPPLEMENTARY TEXT}

Estimation of fishing pressure index based on multi-criteria decision analysis

Given that primary data on fishing vessel locations were not available for all spatial and temporal scales, a methodological approach based on GIS-based multi-criteria decision analysis (GIS-MCDA) was used to estimate a fishing pressure index (FPI) for bottom trawl in the Mediterranean Sea. For the current work average FPI values per GSA for the years 1994, 2004 and 2014 were used.

This method produces a fisheries footprint by taking into consideration several interactions with other anthropogenic or environmental factors. The methodology is further described in Kavadas et al. (2015) and is considered as a modified work based on data from 1994 to 2014. The method is applied to three categories of vessel length: a) $0-12 \mathrm{~m}, \mathrm{~b}) 12-24 \mathrm{~m}$ and c) $24-40 \mathrm{~m}$.

The analytic hierarchy process (AHP) and fuzzy logic were applied in an effort to estimate the FPI which was perceived as the fuzzy product of two indices: the fishery suitability index $(\mathrm{Sc})$ and the activity index (Ac) based on the spatial distribution of registered fishing vessels in the Mediterranean Sea:

$\mathrm{FPI}=\mathrm{Sc} \times \mathrm{Ac}$

To this end, we identified the most influential components and criteria affecting bottom trawlers. Each criterion was assigned a rank of order of importance by expert judgement. The final rankings used for all criteria under study are presented in Table A1. The criteria were the following:

Bathymetry (source: EMODNET).

Distance from coastline (estimated by ARCGIS proximity tool "near". ESRI, 2011).

Annual chlorophyll $a$ concentration (average for the period 2002-2014; source http://oceancolor.gsfc. nasa.gov/ $\mathrm{cms} /$ ).

Fisheries restricted areas (legislation; source MEDISHEH).

No-take zones: based on depth and annual restrictions.

Sc estimation from the investigated criteria was carried out as follows: (i) creation of spatial information and calibration of each criterion according to a scale of evaluation and formation of the hierarchical structure of the multiple criteria problem; (ii) implementation of the AHP to estimate the relative importance of the evaluation criteria; (iii) application of the weighted linear combination method using the weights (priority vectors) to estimate the suitability index; (iv) standardization on a scale from 0 to 1 with linear fuzzy membership.

The Ac for each fishing category and length segmentation by registration port (VAIp) was based on vessel length and gross tonnage for the years 1994, 2004 and 2014. The methodology used to estimate Ac consisted of the following steps: (i) implementation of the optimal interpolation method on VAIp to estimate values at a spatial cell level (VAIc); and (ii) implementation of the optimal fuzzy membership in VAIc to represent numerically the degree to which a given measure of criteria within a grid cell belongs to a fuzzy set. The study area was gridded with a spatial resolution of $0.01 \times 0.01$ decimal degrees. Each of these cells was assigned the corresponding values for each of the MCDA-modelled criteria.

Table S1. - Ranking of the criteria taken into account in MCDA per length overall (LOA) segmentation. The higher the grade, the more favourable the area is for trawl fishing activities. The model includes the following no-take zones: a) banned areas (annually), b) depth $>500 \mathrm{~m}$, for LOA 0-12 m, and c) depth >800 $\mathrm{m}$ for LOA $>12 \mathrm{~m}$.

\begin{tabular}{|c|c|c|c|c|c|c|c|}
\hline Bathymetry (m) & LOA 0-12 & $\begin{array}{c}\text { Grade } \\
\text { LOA 12-24 }\end{array}$ & LOA 24-40 & $\begin{array}{l}\text { Distance from coastline } \\
\text { (nautical miles) }\end{array}$ & LOA 0-12 & $\begin{array}{c}\text { Grade } \\
\text { LOA 12-24 }\end{array}$ & LOA $24-40$ \\
\hline $0-50$ & 3 & 3 & 3 & 1.5 & 0 & 0 & 0 \\
\hline $50-100$ & 5 & 5 & 5 & $1.5-3$ & 5 & 5 & 5 \\
\hline $100-200$ & 4 & 5 & 5 & $3-6$ & 5 & 5 & 5 \\
\hline $200-500$ & 1 & 4 & 4 & $6-12$ & 4 & 5 & 5 \\
\hline$\underline{500-800}$ & 0 & 1 & 2 & $\geq 12$ & 3 & 4 & 5 \\
\hline $\begin{array}{l}\text { Chlorophyll } a \\
\left(\mathrm{mg} \mathrm{m}^{-3}\right)\end{array}$ & \multicolumn{3}{|c|}{$\begin{array}{c}\text { Grade } \\
\text { All classes of LOA }\end{array}$} & $\begin{array}{l}\text { Legislation } \\
\text { (total months of banning) }\end{array}$ & \multicolumn{3}{|c|}{$\begin{array}{c}\text { Grade } \\
\text { All classes of LOA }\end{array}$} \\
\hline$>1$ & \multicolumn{3}{|c|}{1} & available areas & \multicolumn{3}{|c|}{5} \\
\hline $0.73-1$ & \multicolumn{3}{|c|}{4} & ban $<2$ & \multicolumn{3}{|c|}{4} \\
\hline $0.46-0.73$ & \multicolumn{3}{|c|}{5} & ban 2-6 & \multicolumn{3}{|c|}{3} \\
\hline $0.23-0.46$ & \multicolumn{3}{|c|}{4} & ban 6-11 & \multicolumn{3}{|c|}{2} \\
\hline $0.1-0.23$ & \multicolumn{3}{|c|}{2} & ban 12 & \multicolumn{3}{|c|}{0} \\
\hline
\end{tabular}



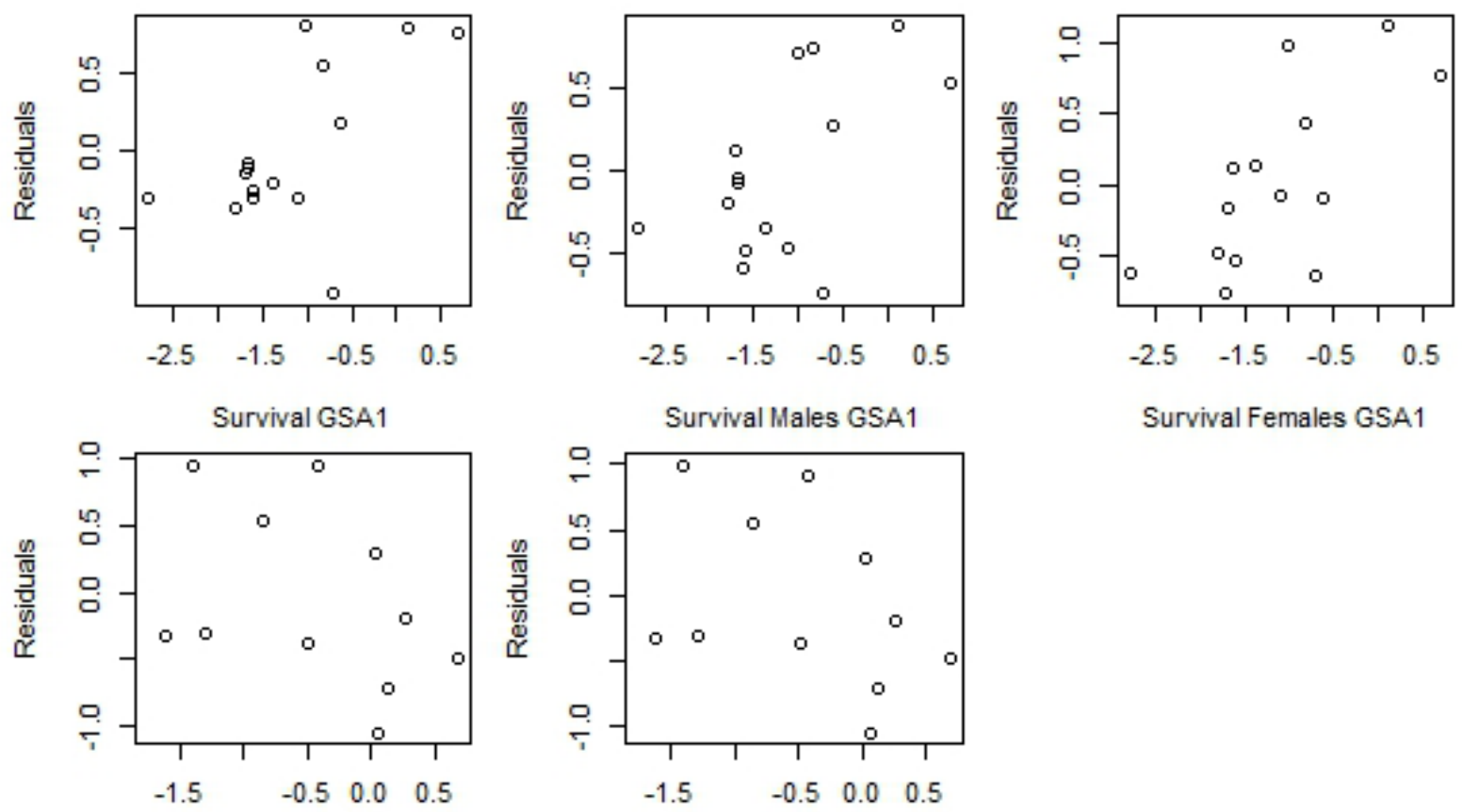

Survival Females GSA1
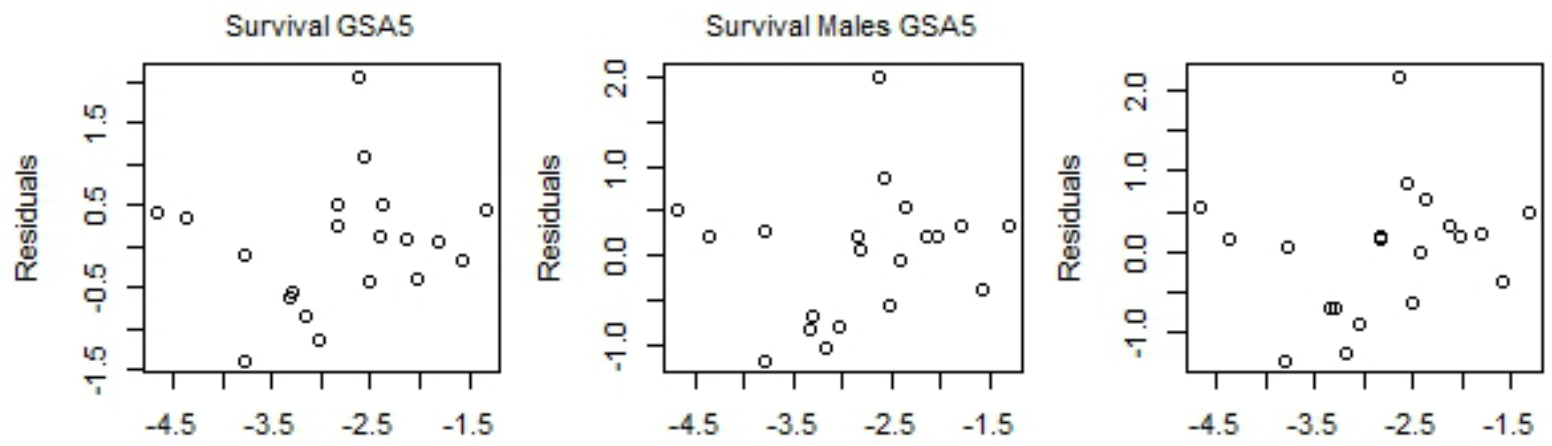

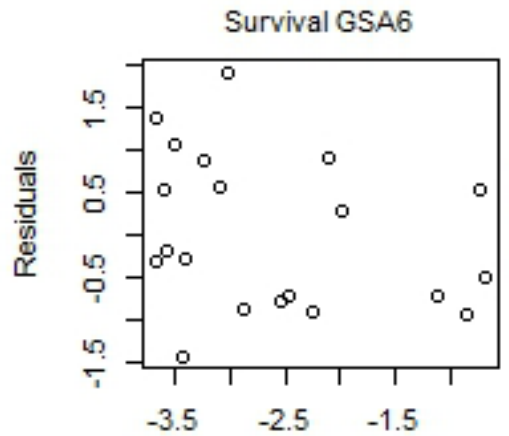

Survival GSA7

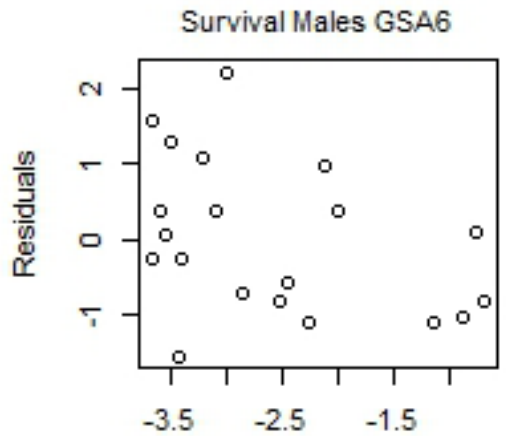

Survival Males GSA7

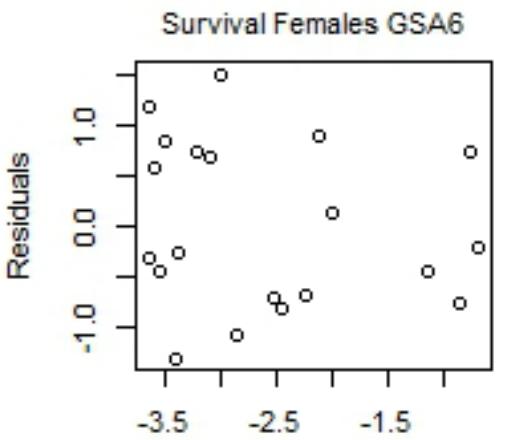

Survival Females GSA7

Fig. S1. - Model residuals against response variable for the best linear model obtained for each GSA (Table 1) for all individuals (left), males (centre) and females (right). Here, models for GSA-1, GSA-5, GSA-6 and GSA-7 are shown, 


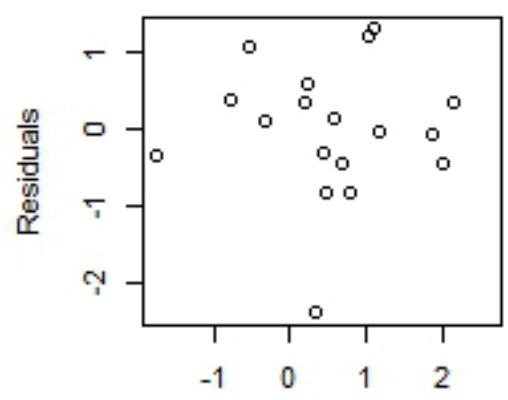

Survival Males GSA8
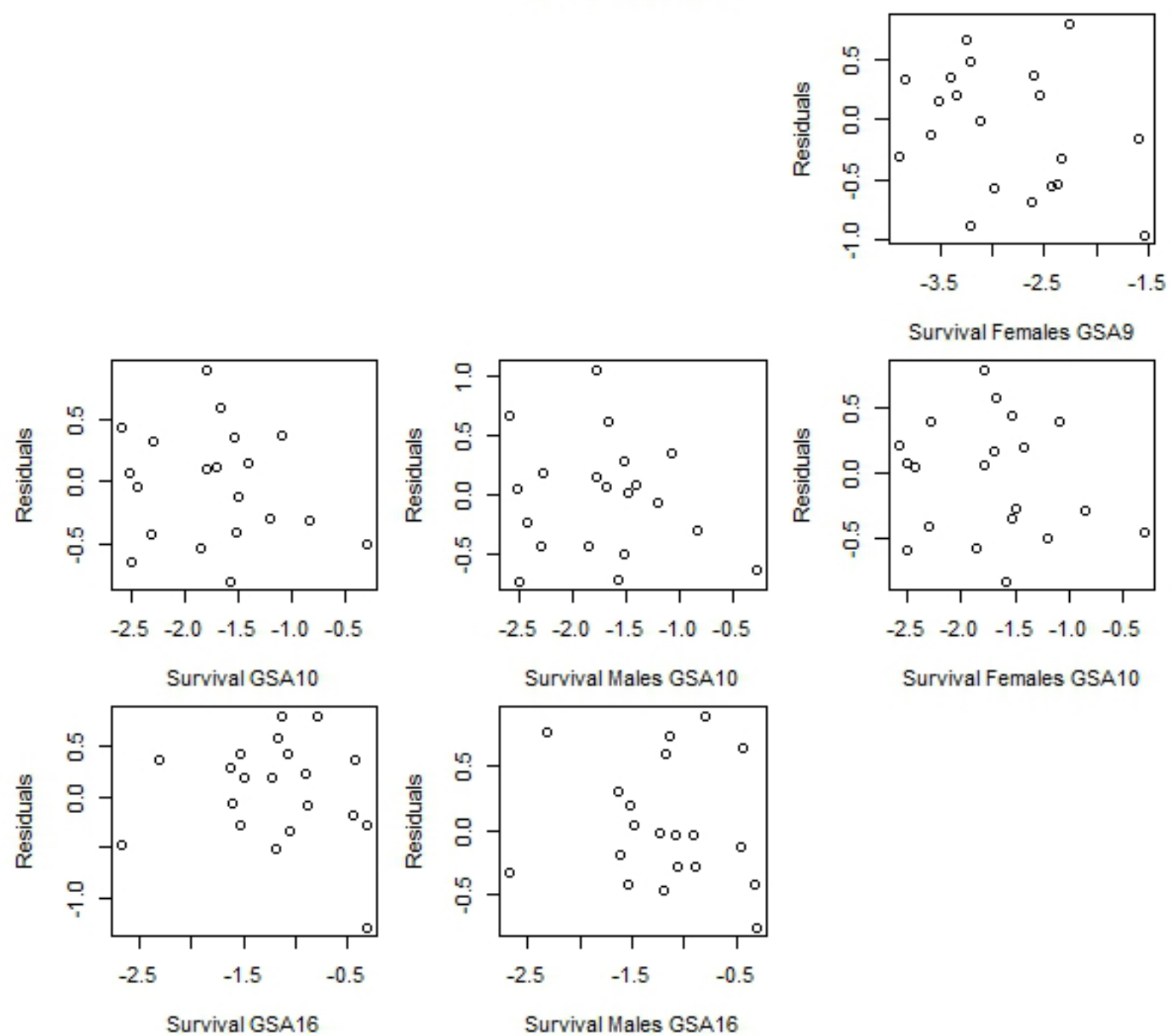

Survival Females GSA10

Fig. S1 (Cont.). - Model residuals against response variable for the best linear model obtained for each GSA (Table 1) for all individuals (left), males (centre) and females (right). Here, models for GSA-1, GSA-5, GSA-6 and GSA-7 are shown, 

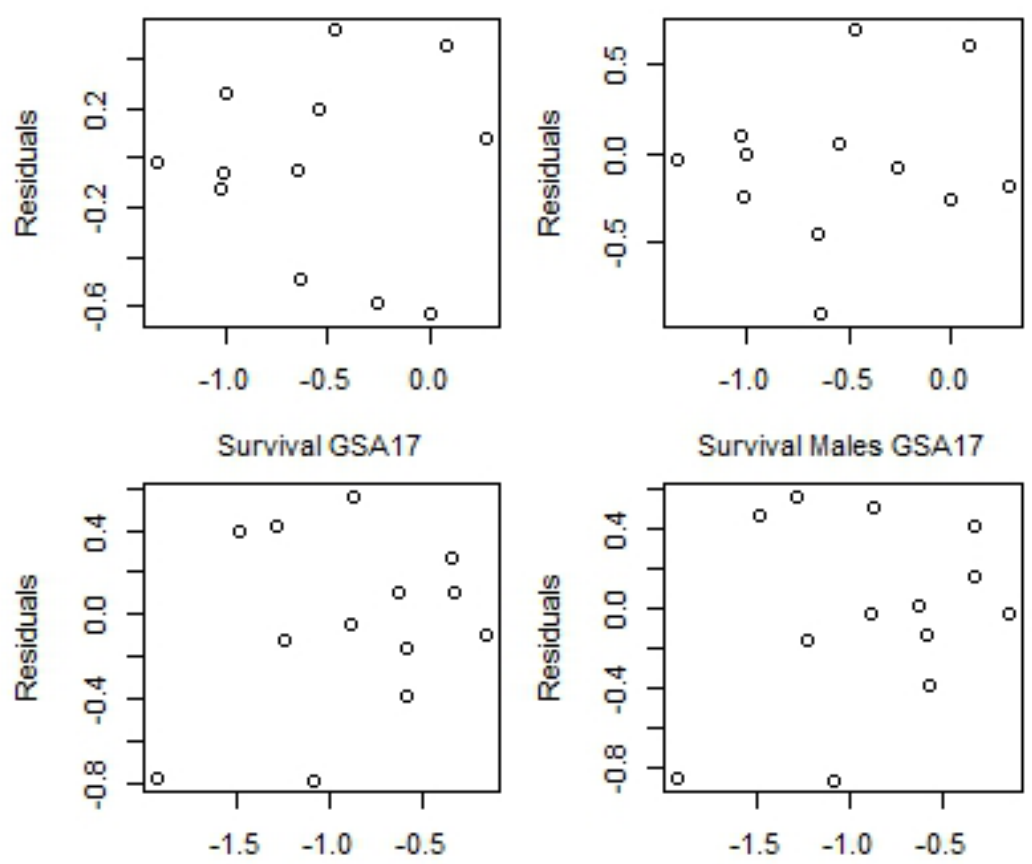

Survival GSA18

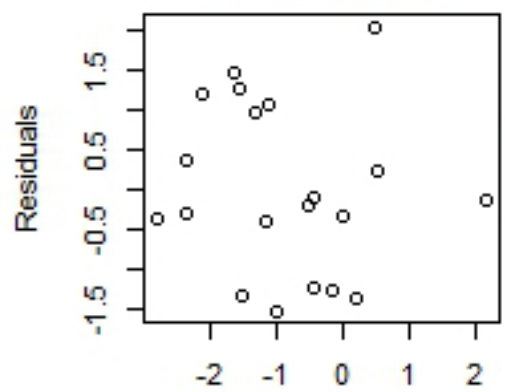

Survival GSA19

Survival Males GSA17

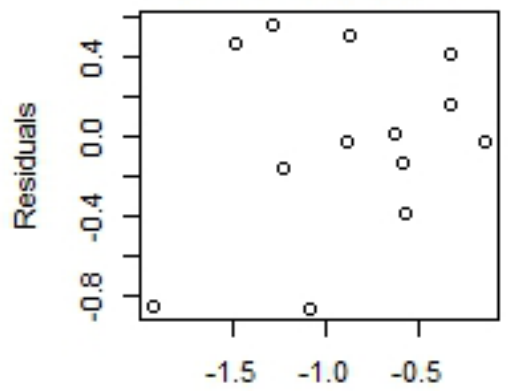

Survival Males GSA18

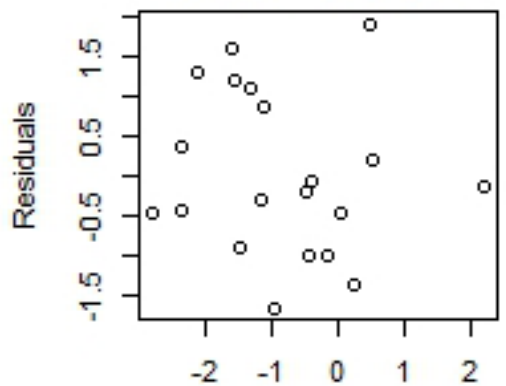

Survival Males GSA19

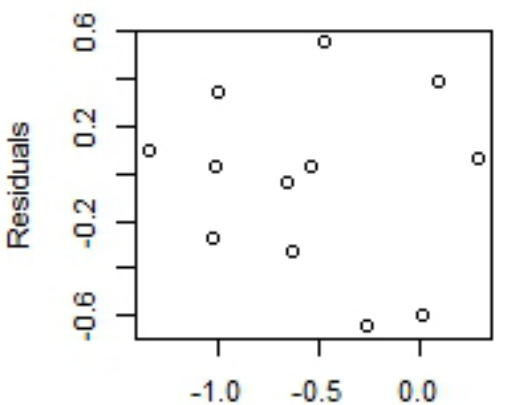

Fig. S1 (Cont.). - Model residuals against response variable for the best linear model obtained for each GSA (Table 1) for all individuals (left), males (centre) and females (right). Here, models for GSA-1, GSA-5, GSA-6 and GSA-7 are shown,

\section{4}

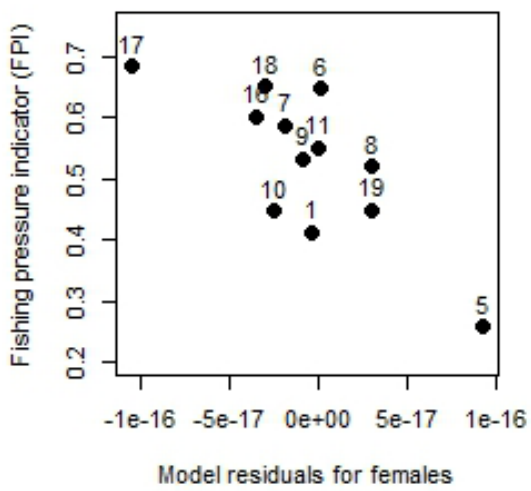

2004

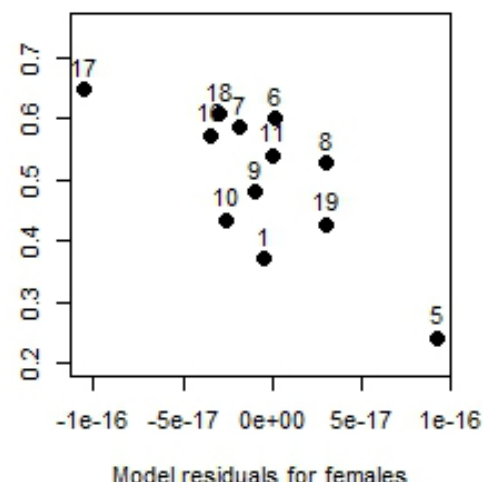

2014

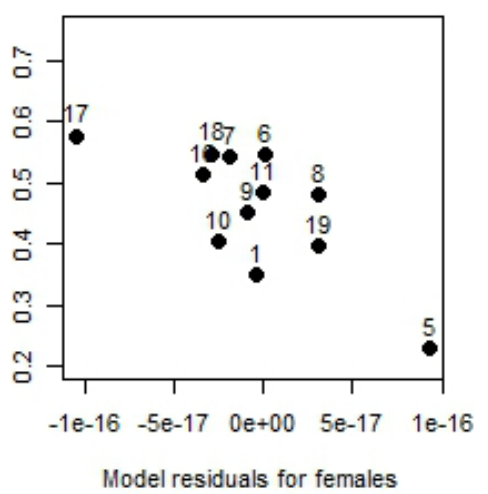

Fig. S2. - Scatter plot of the residuals of the global survival model for females applying a linear model on the standardized variables (mean 0 and variance 1) and the fishing pressure indicator for 1994 (left), 2004 (centre) and 2014 (right). While the negative correlations obtained between the fishing pressure indices and the residuals of the global model were very low $(-0.23<$ rho $\leq 0.17$, right), those correlations for females were relatively high $(-0.62<$ rho $\leq 0.60$, left $)$. However, these high correlation values are forced by two extreme values of FPI: the lowest in the Balearic Islands (GSA-5) and the highest in the northern Adriatic (GSA-17). 